\title{
Yunt Dağı Karakılınçlı Köyü Camii'nde Yazının Bezeme Unsuru Olarak Kullanımı ve Yapının Mimari Analizi*
}

Öz

\author{
Ramazan Uykur*
}

Yunt Dağı, Ege Bölgesi'nin batısında yer alan, Bakırçay ve Gediz ırmaklarının kuzeyden ve güneyden doğal sınır oluşturduğu bölgedir. Yunt Dağı ve çevresinin Türkler tarafindan ele geçirilmesi ise Saruhanoğlu'larının Manisa Kalesi'ni fethettiği tarihten daha önce olduğu tahmin edilmektedir. Söz konusu eser Yunt Dağı'nın Karakılınçlı Köyü'nde, bulunmakta ve kuzey cephesinde yer alan kitabeye göre 1325H./1907-08M. yılında inşa edilmiştir. Bu çalışma ile daha önce hakkında bir araştırma yapılmamış, neredeyse hiç bilinmeyen bir eseri, ilk defa mimari, plân ve süsleme özellikleriyle bilim dünyasına tanıtmak amaçlanmaktadır. Böylece yapıyı belgeleyerek, eseri ve eserin karakterini oluşturan yazı bezemelerin bir an önce korunmaya alınmasını sağlamak hedeflenmektedir.

Incelemelerimiz sırasında caminin harim duvarlarının celî divânî, sülüs ve kûfi istifli yazılarla dikkat çekecek şekilde bezenmiş olduğu görülmüştür. Bunlar içinde en dikkat çekeni ise batı duvarındaki Yedi Uyurlar konulu geminin bulunduğu resimli yazıdır. Çalışmada bütün yazılar okunarak metin içinde Arapça okunuşları ve anlamlarıyla açıklanmıştı. Ayrıca araştırmada, eserin bir takım ciddi sorunları bulunduğu da tespit edilmiştir. Yapı cephelerinde oluşan derin çatlakların duvarlarda nem oluşturduğu ve duvar sıvasının altının boşaldığı, yapıda gerçekleşen tamirat, tadilat ve badana işlerinde yazıların ciddi tahribata maruz kaldığı görülmüştür. Bozulmalara dair tespit ve öneriler metin içinde sunulmuştur. Anahtar Kelimeler: Manisa, Yunt Dağı, Karakııınçı Köyü Camii, Hattat Hüseyin Avni, Yedi Uyurlar Motifi

\section{The Use of Script as Decoration Element in Yunt Mountain Karakilinçli Village Mosque and Architectural Analysis of The Structure}

Abstract

Yunt Mountain is located on a spot where Bakırçay and Gediz rivers form a natural border to the north and south of the Aegean Region. The conquest of Yunt Mountain and its surroundings by the Turks is thought to be earlier than the date that the Principality of Saruhanoğulları seized the stronghold of Manisa. The mosque was built in 1325/1907-08 according to the inscription on its northern facade in Karakılınçlı Village of Yunt Mountain in Yunus Emre District of Manisa Province. Our aim is to have the structure protected immediately and then to introduce it to academic world for the first time in detail and have it registered as a cultural asset without exposing any further damage. It is therefore important that both the building and the scripts that make up the character of the structure should be preserved as soon as possible.

In our study, we have seen that the interior walls, referred to as harim, of the mosque were decorated with quite attractive calligraphy known as celî divânî, sülüs and kûfi istif. The most remarkable among those is the pictorial script in the form a ship depicting "Seven Sleepers" on the western wall of the mosque. All inscriptions are examined through a detailed research and explained in text with their meanings along with the Arabic pronunciation. In the study, it was detected that the deep cracks on the building facades have resulted in moisture accumulation on the walls and the surface underneath the wall plaster was stripped. For this reason, at any time it is highly likely that the plaster will fallout, be flaked and the scripts will be lost. Furthermore, the scripts were damaged during the restoration, renovation and whitewashing works of the building. In particular, we have observed that by intervening with the chemical paints to the scripts in the niche of mihrab, both the characters and the colours from the madder were deteriorated accordingly. The entire findings and recommendations are further presented in the text.

Keywords: Manisa, Yunt Mountain, Karakilinçli Village Mosque, Calligraphist Hüseyin Avni, Seven Sleepers

* DOI:10.16971/vakiflar.601466

Makalenin Geliş Tarihi / Received Date: Ağustos 2019 / August 2019

Makalenin Kabul Tarihi / Accepted Date: Temmuz 2020 / July 2020

** Doç. Dr. Manisa Celal Bayar Üniversitesi, Fen Edebiyat Fakültesi, Sanat Tarihi Bölümü, ramazan.uykur@cbu.edu.tr;

ORCID: 0000-0001-5621-3687 


\section{Giriş}

Yunt Dağı, Ege Bölgesi'nin batısında Manisa'nın Kırkağaç ve Akhisar ovalarından Ege Denizi'ne doğru kuzeydoğu ve güneybatı yönünde uzanan bölgedir. Doğudan Kırkağaç ve Akhisar ovaları ile Kadı Dağı, güneydoğudan Saruhanlı Ovası, Kum Çayı Boğazı ve Medar Çayı; batıdan ise Çandarlı Körfezi ile sınırlanmaktadır. Yüzölçümü yaklaşık 3.521 km² dir (Eroğlu vd. 2012: 131).

Bölgenin Yunt Dağı ismiyle ilk defa ne zaman anılmaya başlandığı bilinmemektedir. Rastlanılan en erken kayıt olan 1575 yılı Manisa Tahrir Defterinde Yund Dağı şeklinde geçtiği görülmektedir. Daha sonraki belgelerde ise Yund ve Yunt Dağı'nın yanı sıra Yurt Dağı şeklinde kullanımına rastlanmaktadır (Sezgin, 2017: 30). Bölge İlk çağlardan itibaren iskâna tabi olmakla birlikte Yunt Dağı üzerinde kurulan en büyük yerleşim Aigai (Nemrudkale) antik kentidir. Yapılan kazı ve yüzey araştrrmaları, kentin M.Ö. 700 civarında kurulduğunu göstermektedir. Arkeolojik veriler, özellikle Helenistik dönemde, Yunt Dağı'nın önemli bir bölümünün Aigai'nin kontrolünde olduğu yönündedir (Sezgin, 2017: 22-23; Akurgal, 1993: 360-361).

Yunt Dağı ve çevresinin Türkler tarafindan ele geçirilmesi Saruhanoğuluları'nın, Manisa Kalesi'ni aldığı 1313 yılından önce olduğu düşünülmektedir. Bölgenin Saruhanoğlu Beyliği'nin fethinden 15. yüzyıIın ikinci yarısına kadar, düşük bir nüfus barındırdığı tahmin edilmektedir. Manisa'nın, Sultan II. Murat (1421-51) döneminden itibaren önemli bir sancak merkezi konumuna yükselmesiyle, Yunt Dağı'nın aşiretler tarafindan iskânı yoğunluk kazanmıştır (Sezgin, 2017: 28-29).

16. yüzyılda Manisa'nın nahiyeleri şunlardı: Yengi, Belen, Palamut, Yunt Dağı ve Emlak. Emecen'in verdiği, 1575 yılındaki idari birimler ve iskân merkezleri sayısını gösteren tabloya göre Yunt Dağı'nın 20 köyü ve 1 mezrası bulunuyordu (Emecen, 1989: 112, 214).

Yunt Dağı, 16. yüzyıldan, 19. yüzyılın ikinci yarısına kadar Manisa'nın merkez nahiyelerinden biri olmuştur. Yunt Dağı bölgesinde bu yüzyıla kadar sakin olan hayat 19. yüzyılda aşiretlerin yerleştirilmesiyle hareketlenmeye başlamış; bölgede ticaret, ziraat ve sanat dalları gelişmiştir. Özellikle at yetiştiriciliğinde Akhisar ve Turgutlu ile beraber Saruhan/Manisa'nın en iyi ve dayanıklı binek atları yetiştirilmekte idi (Uluçay, 1942: 12, 53). Ayrıca bölgenin sarp, ormanlık ve kayalık olması sebebiyle Saruhan Sancağı içinde en yoğun eşkıyalık hareketleri de bu civarda görülmüştür (Uluçay, 1955: 2, 70, 145, 208).

Gökçen’in yayınladığı H. 1280-1290/M. 1863-1874 yıllarına ait Sicil Defterlerine göre aşiretlerin son iskânında dağılışlarını gösterir cetvelde; Aşiretlerin Yunt Dağı'nda Belen, Osmancalı, Mamaklı, UzunhasanIı, Beydere, Yağcılar Sarınasuhlar, Camlıca, Yeniceköy ve Karasılı köylerine yerleştirildiği anlaşılmaktadır (Gökçen, 1946: 94-95).

\section{Caminin Yeri ve Yapım Tarihi}

Yapı, Manisa i̇li, Yunus Emre İlçesi'ne bağlı, Yunt Dağı'nın Karakılınçlı Köyiçi Mevkiinde, 2. pafta, 554. parselde bulunmaktadır ${ }^{1}$ (Fotoğraf 1 ). Yapının kuzey cephesinde son cemaat yerine girişi sağlayan, kemer gözünün üzerinde taş bir kitabe içerisinde 1325H./1907-08M. yılında yapıldığını belirten inşa tarihi bulunmaktadır (Fotoğraf 3). Yapıya ait bir vakfiyeye ise rastlanmamıştır.

1 Haziran ve Temmuz 2019 tarihlerinde yapılan incelemelerde benimle birlikte alanda çalışan, Sanat Tarihçi Doğukan Yaycı'ya, yardımlarını esirgemeyen ve rölöveleri çizen Mimar Timur Çelik'e, gösterdiği kolaylık ve misafirperverlik için cami imamı Bilal Güçlü'ye; kitabelerin bazılarının okunmasında emeği geçen araştırmacılar İlyas Yorulmaz ve Hikmet Zeyveli'ye minnettarlı̆ımı bildirir ve teşekkürlerimi sunarım. Ayrıca yapılan araştırma neticesinde yapının tescilsiz bir eser olduğu anlaşılmış ve Temmuz 2019 tarihi itibariyle İzmir 2 Numaralı Bölge Koruma Kurulu'na yapının tescil işlemlerinin başlatılması için tarafimdan başvurulmuş ve yapı kültür varlı̆̆ı olarak tescil edilmiştir. 


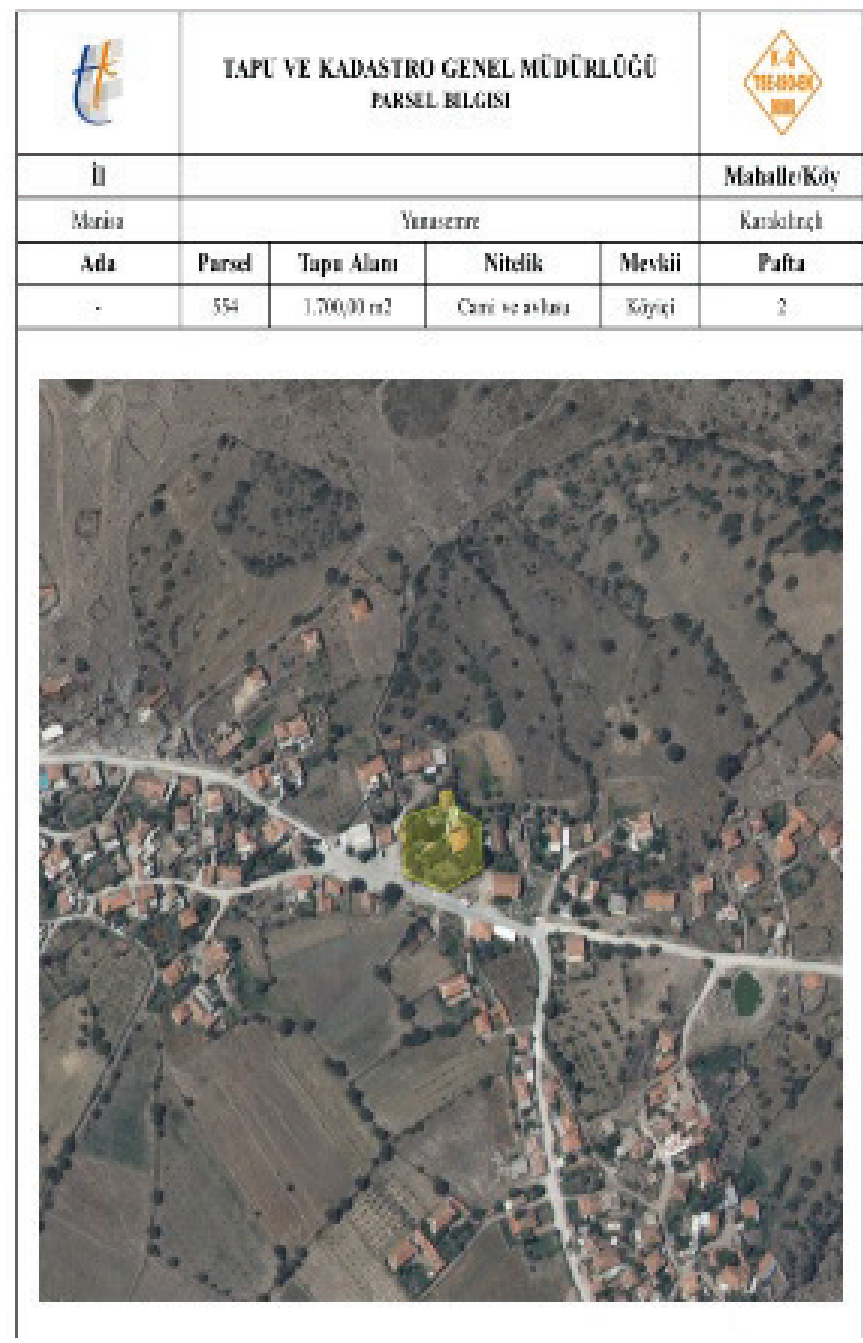

Fotoğraf 1. Karakılınçlı Köyü Camii, Tapu ve Kadastro Genel Müdürlüğü konum ve parsel bilgisi ve hava görüntüsü (2019).

\section{Mimari Özellikleri ve Yazı Bezemeleri}

Cami, kuzey-güney yönünde hafif eğimli bir arazi üzerinde, mihrap duvarına göre enlemesine dikdörtgen plânlı harim ve bunun kuzeyindeki son cemaat yerinden oluşur. Caminin kuzeybatı köşesine yapıya bitişik, -köylülerin ifadesiyle 1970’lerde inşa edilmiş- yığma teknikle örülmüş, beton briket malzemeli bir minare eklenmiştir. Minarenin kaidesi sekizgen, gövdesi silindir ve tek şerefelidir. Ancak yapının kuzeydoğusunda avlu içinde camiden bağımsız, üzerindeki tarihe göre 1937 yılında yapıldığı anlaşılan, gövdesi moloz taş, korkulukları betonla inşa edilen köşk minaresi bulunmaktadır. Köşk minarenin yanına yakın zamanda bir de şadırvan eklenmiştir. Camide inşa malzemesi olarak, düzgün kesme taş kullanılmış ve taş yüzeylerine kazıma tekniğiyle baklava desenleri işlenmiştir. Böylece yapının cephelerine hareket kazandırılarak dikkat çekici ve belirgin hâle getirilmiştir. Taş aralarında bağlayıcı olarak kireç derz kullanılmıştır. Kırma çatılı yapının üzeri kiremit kaplıdır ve iki sıra kademeli taş saçak yapının bütün cepheleri boyunca devam etmektedir. Son cemaat yeri ve harimin tavanı ahşap kaplamalıdır. Yapı günümüzde ibadete açıktır ve kapsamlı bir onarıma ihtiyaç duymaktadır. 


\section{Cepheler}

Yapının giriş bölümü olarak tasarlanan kuzey cephesinde iki kademeli cephe düzeni ile karşılaşılır. Alt seviyede; dördü bağımsız, ikisi beden duvarına bitişik, alt sütun sırasının taşıdığı beş kemer açıkığından son cemaat yerine girilmektedir. Kemerler yuvarlak formlu, kemerlerin oturduğu sütun başlıkları ve sütunların kaideleri dikdörtgen, sütun gövdeleri ise sekizgendir. Günümüzde kemer aralarına belli bir seviyeye kadar taş duvarlar örülmüş, duvarların üzeri ise ahşap doğramalarla kapatılmıştır. Böylece ortadaki kemer açıklığı kapıya, yanındakiler ise pencereye çevrilerek son cemaat yeri kapalı hâle dönüştürülmüştür. Kapı olarak kullanılan kemer açıklığının üzerinde taş pano içerisinde simetrik olarak servi ağacı, hilal ve alt kollu yıldız motifleri; bu bezemelerin ortasında ise "Mâşâallah" ve Hicri tarihle "1325" yazılmıştır (Fotoğraf 2-3).

Cephenin üst seviyesinde ise taş söveli üç pencere bulunur. Pencerelerden ortadaki gül pencere, bunun doğu ve batısındakiler yuvarlak kemerli dikdörtgen penceredir. Bu cephede yapıyla uyumsuz eklentiler mevcuttur. Son cemaat yerinin önüne metal direkli sundurma yapılmış, caminin cephesine de floresan lambalar takılmıştır (Fotoğraf 2).

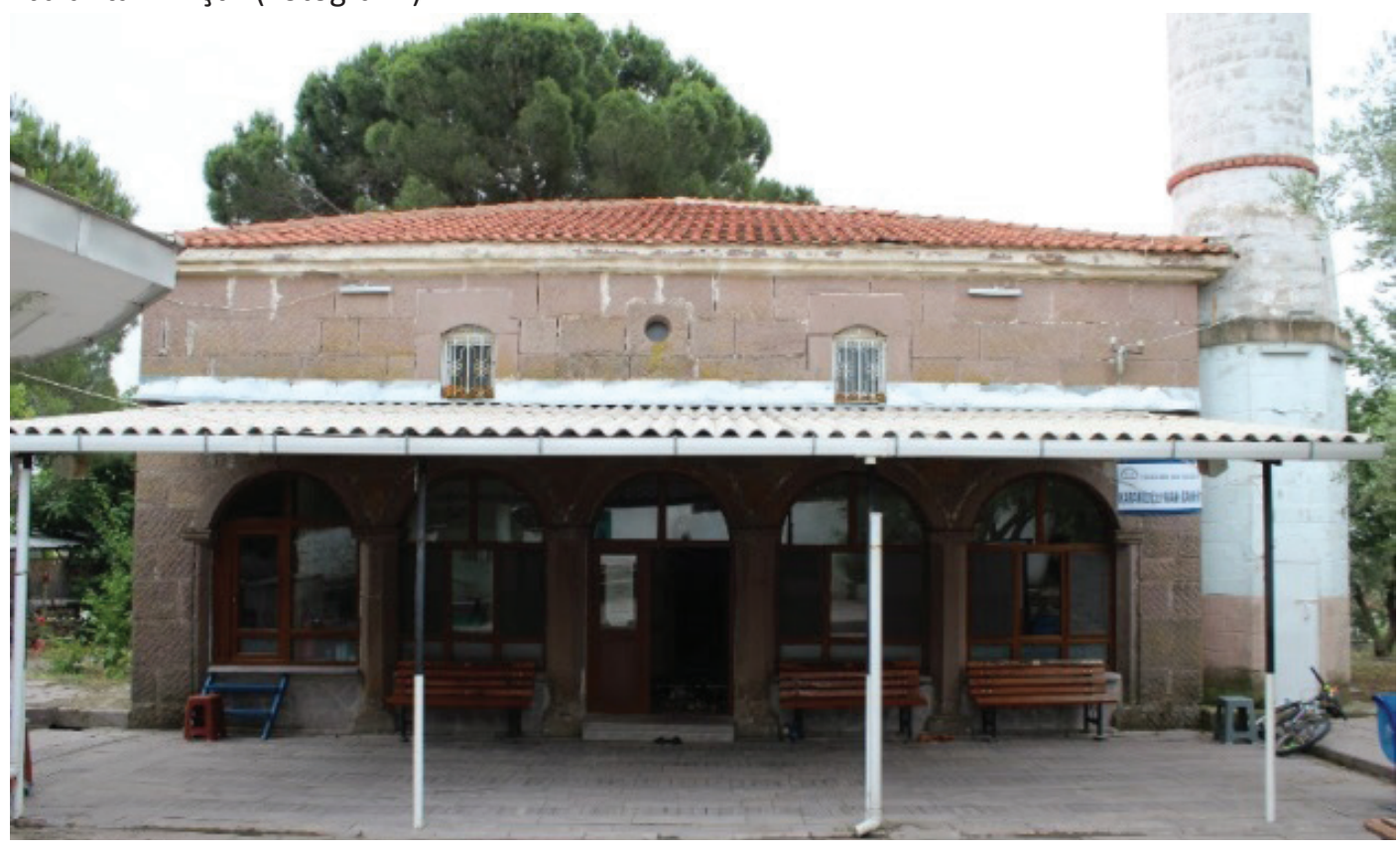

Fotoğraf 2. Kuzey cepheye bakıss.

Yapının diğer cephelerinde ise çift sıralı pencere düzeni uygulanmıştır. Bu düzenleme şöyledir: Doğu cephede alt seviyede dikdörtgen tipte bir, üst seviyede gül ve dikdörtgen formunda pencere; güney cephede alt seviyede iki dikdörtgen, üst seviyede iki gül pencere; bat cephede alt seviyede dikdörtgen, üst seviyede ise gül ve dikdörtgen tipte pencere tasarımları uygulanmıştı. Yapıda dikdörtgen pencerelerin tamamı taş söveli, yuvarlak kemerli ve söve yüzeyleri sadedir. Böylece yapının tüm cephelerinde görülen baklava desenlerinin aksine, söveler sade bırakılıp kontrast bir etki oluşturularak vurgulanmıştr. Ayrıca pencere söveleri beden yüzeyinden dışa doğru taşırılarak belirginleştirilmiştir. Gül pencerelerin söveleri ise yapının cephe taşlarında olduğu gibi baklava desenlidir (Fotoğraf 4-6).

Doğu cephenin güneydoğusunda çatıdan zemine kadar çatlaklar oluşmuş harime su geldiği için yarıklar çimentoyla kapatılmıştır. Çatlağa yakın yere de duvar yüzeyine klima dış ünitesi monte edilmiştir. 

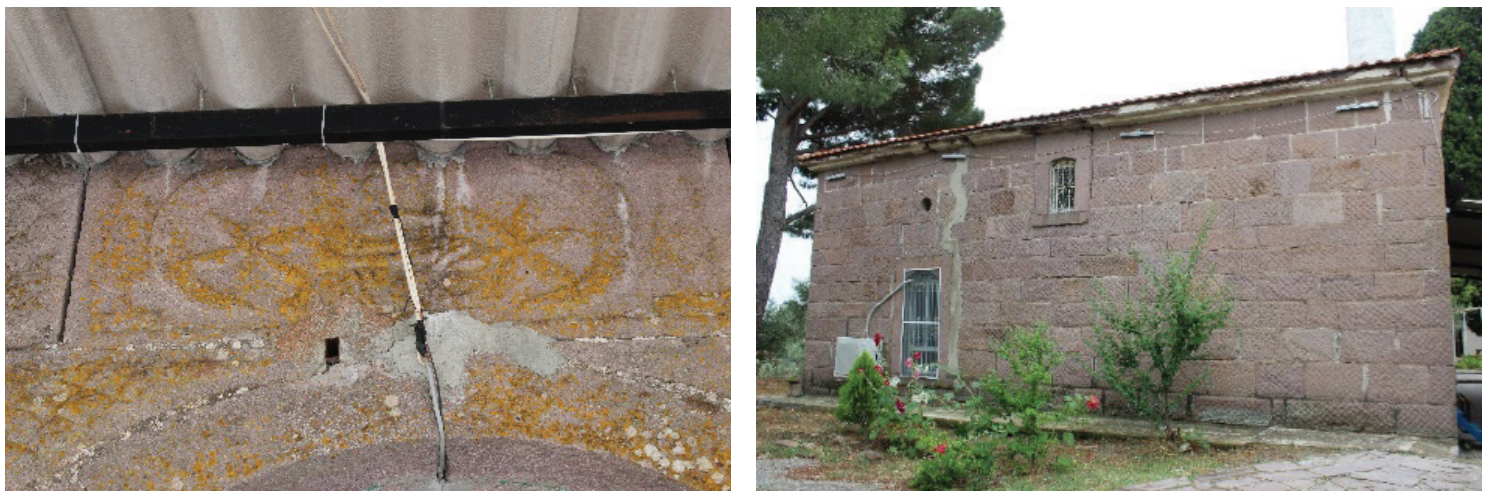

Fotoğraf 3. Kuzey cephede yer alan kitabe ayrıntısı. Fotoğraf 4. Doğu cepheye bakış.

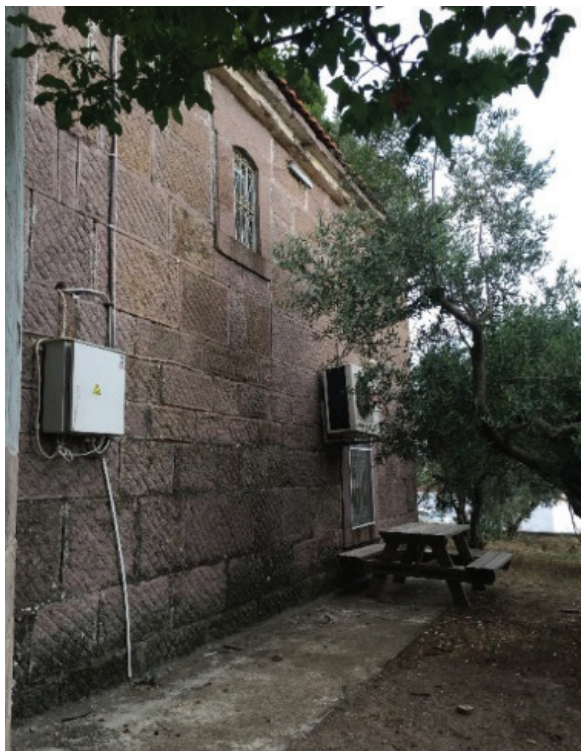

Fotoğraf 5. Güney cepheye bakış.

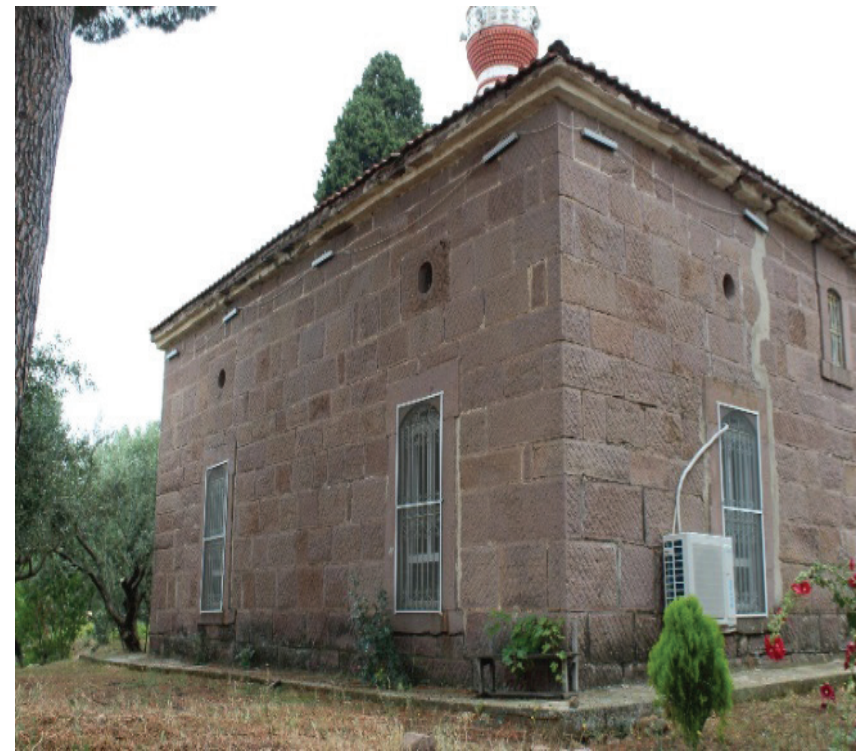

Fotoğraf 6. Batı cepheye bakış.

\section{İç Mekân}

Cami, mihrap duvarına göre enlemesine dikdörtgen bir harim ile kuzeyinde yer alan son cemaat yerinden meydana gelen tek mekânlı bir plân düzenine sahiptir. Son cemaat yeri müdahale öncesi beş kemer açıklığıyla avluya açılıyorken, -daha önce bahsedildiği gibi- yapılan müdahalelerle kapalı hale getirilmiştir. Son cemaat yerinden harime kırmızı bazalt taşından inşa edilmiş taç kapıdan girilmektedir. Taç kapı harim kuzey duvarının merkezinde mihrap eksenindedir. Taç kapının özgün çift kanatlı ahşap kapısı hâlen durmaktadır. Taç kapı kavsara kuşatma kemeri çift kademeli yuvarlak kemerli, içteki kemer yüzeyi sade, dıştaki kemer yüzeyi yivli ve kilit taşı yüzeyden taşırılmak suretiyle vurguludur. Kuşatma kemerleri kademeli sütun başıłılarına oturtulmuştur. Sütun gövdeleri dıştan içe doğru profilli yapılmış ve yüzeyleri yivli kaidelere oturtulmuştur. Böylece bütün bu unsurlar bir arada uyum içinde kullanılarak Gotik etki izlenimi yansıtan taç kapı kurgusu oluşturulmuştur (Çizim 1, Fotoğraf 7). İbadet mekânı pencerelerin az olması sebebiyle loş bir ortama sahiptir. Muhtemelen duvarların yazılarla doldurulacağı önceden plânlandığı için yeterli pencere açılmamıştır. Harimin kuzey duvarı boydan boya kadınlar mahfili şeklinde düzenlenmiştir. Mahfil, son cemaat yerinin üzerine gelecek 
Yunt Dağı Karakılınçıı Köyü Camii’nde Yazının Bezeme Unsuru Olarak Kullanımı ve Yapının Mimari Analizi şekilde inşa edilmiştir. Kadınlar mahfiline çıkış harimden batı-doğu yönünde yerleştirilmiş ahşap korkuluklu onbir basamaklı taş merdivenle sağlanmıştır. Günümüzde kadınlar mahfilinin harime bakan bölümü kafes tekniğinde yapılmış, boyalı ahşap korkulukla kapatılmıştır. Malzemenin form ve tekniği ahşap kısımların özgün haline uygun biçimde yenilendiğini düşündürmektedir. Mahfilin kuzey duvarında üç pencere açılmış; ortadaki gül, iki yandakiler yuvarlak kemerli ve dikdörtgen biçimlidir (çizim 2, Fotoğraf 8).

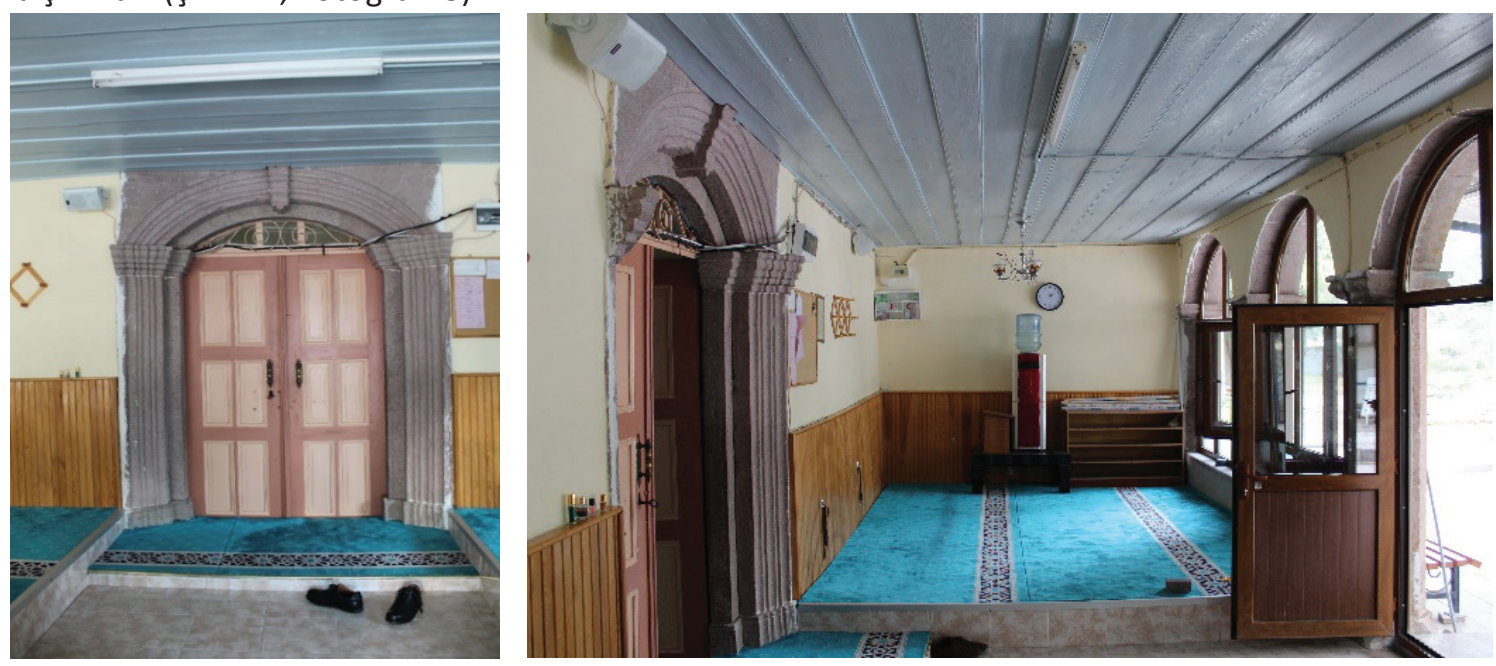

Fotoğraf 7. Son cemaat yerine bakış ve harim taç kapısı.

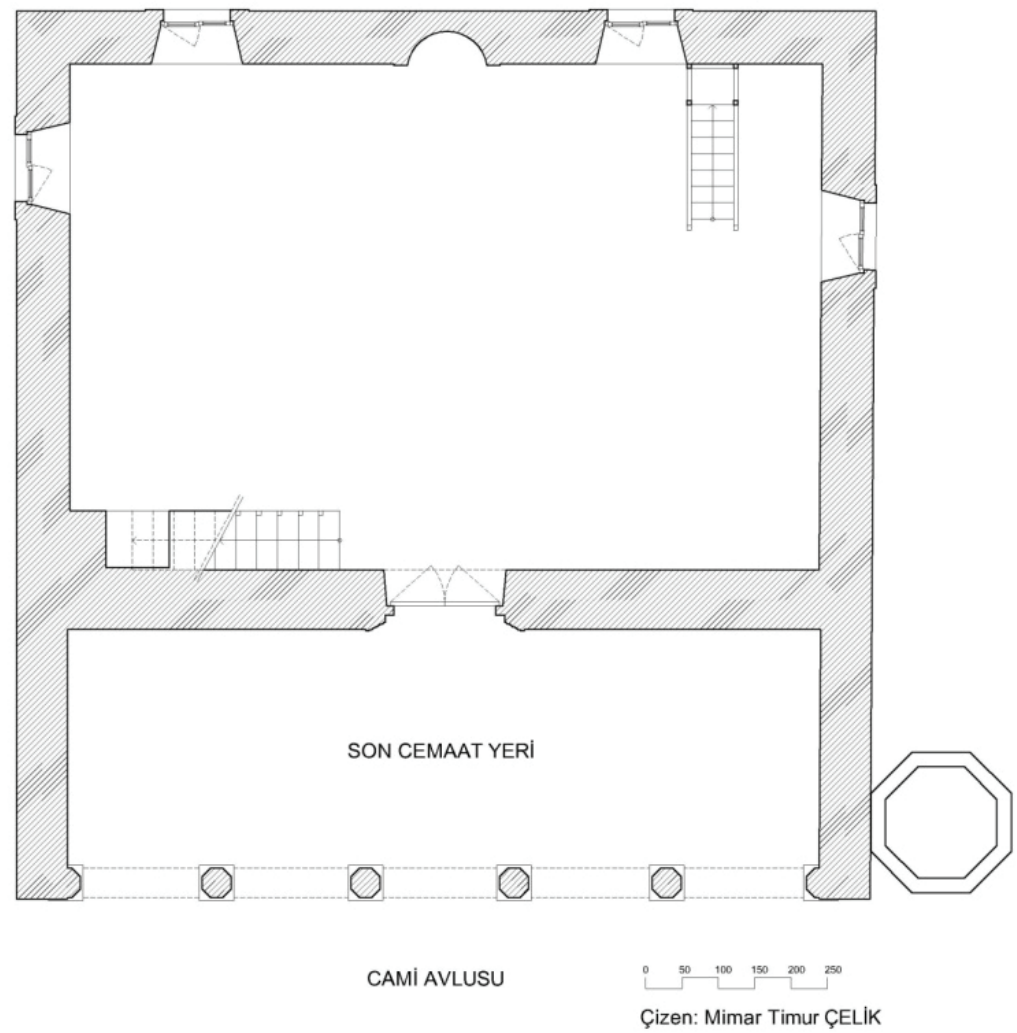

Çizim 1. Karakılınçı Köyü Camii plânı (Mimar Timur Çelik, 2019). 
Ramazan Uykur

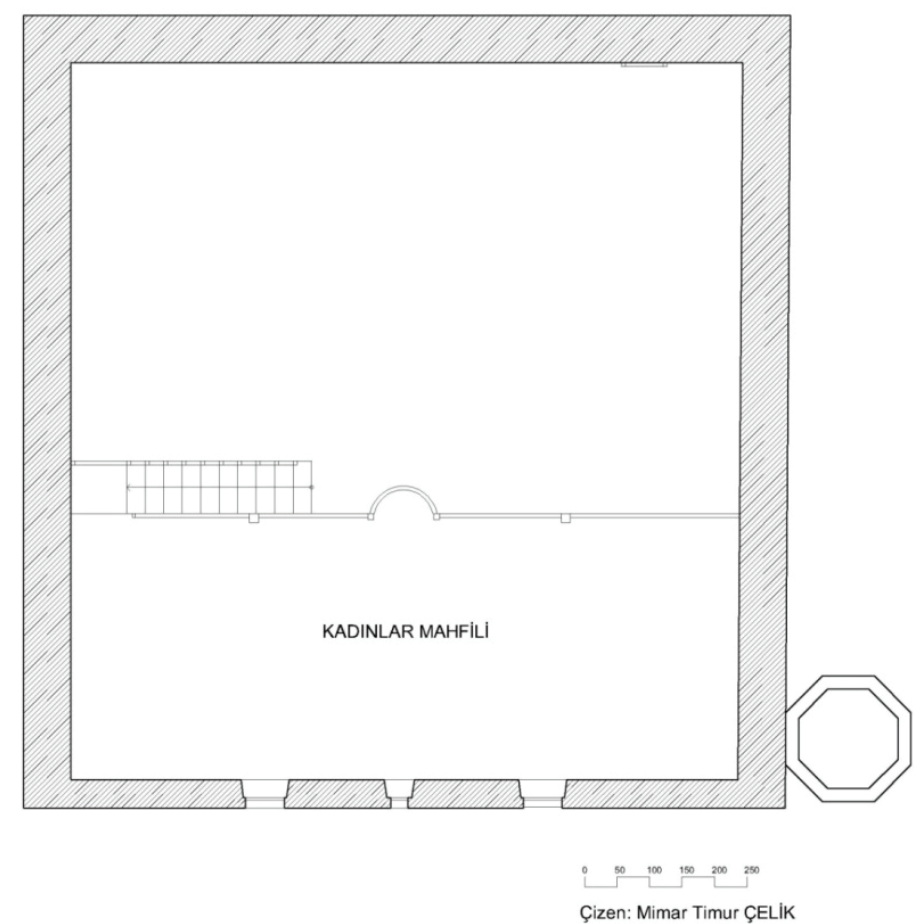

Çizim 2. Karakılınçlı Köyü Camii kadınlar mahfili plânı (Mimar Timur Çelik, 2019).

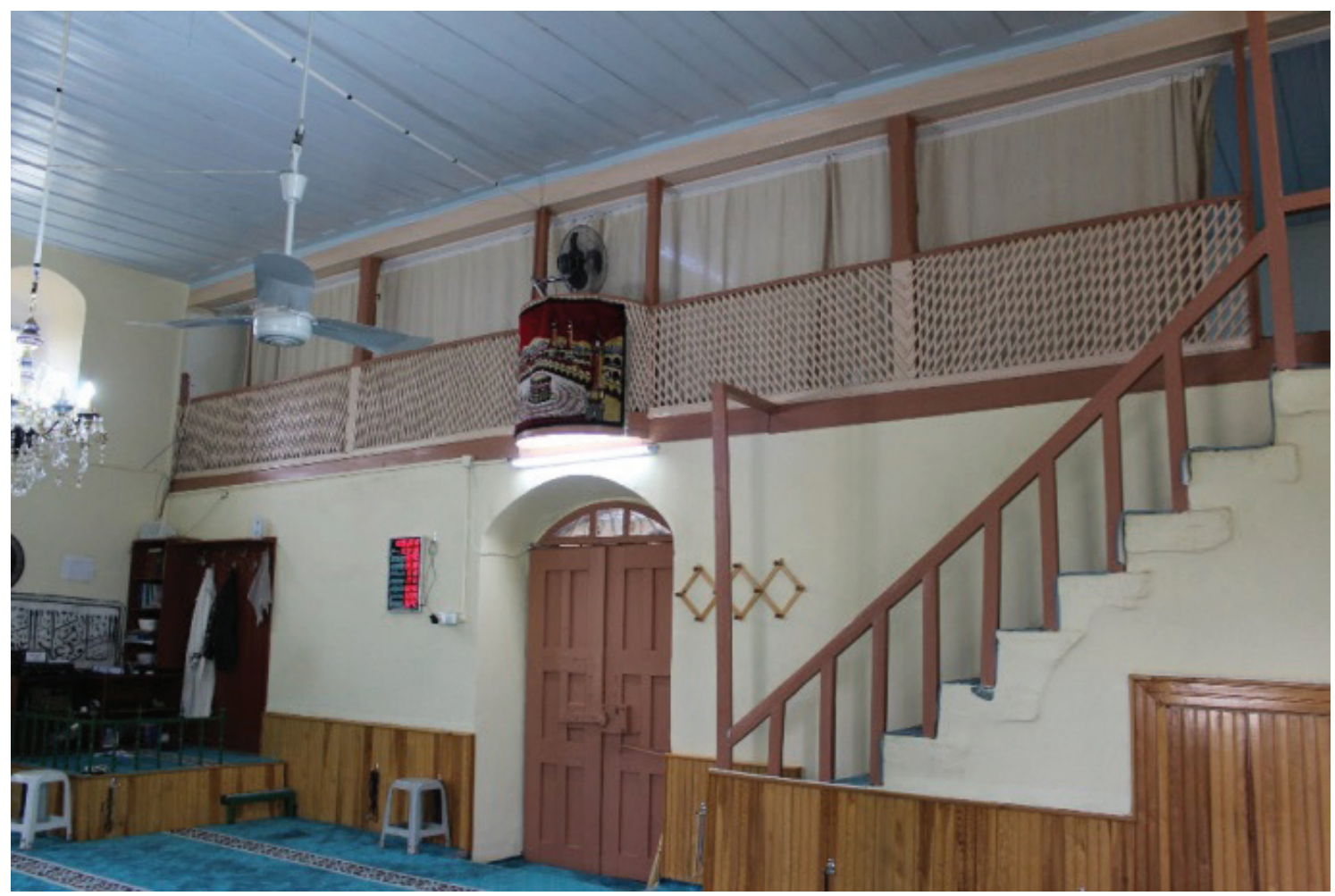

Fotoğraf 8. Harim kuzey duvarı ve kadınlar mahfiline bakış. 
Harimin doğu duvarında alt seviyede bir büyük, dikdörtgen ve yuvarlak kemerli pencere; üst seviyede ise bir gül pencere, bir de yuvarlak kemerli dikdörtgen pencere yer alır. Alt sıradaki büyük pencerenin kuzeyinde ve güneyinde iki sıra halinde yazı bezemelere yer verilmiştir (Fotoğraf 9).

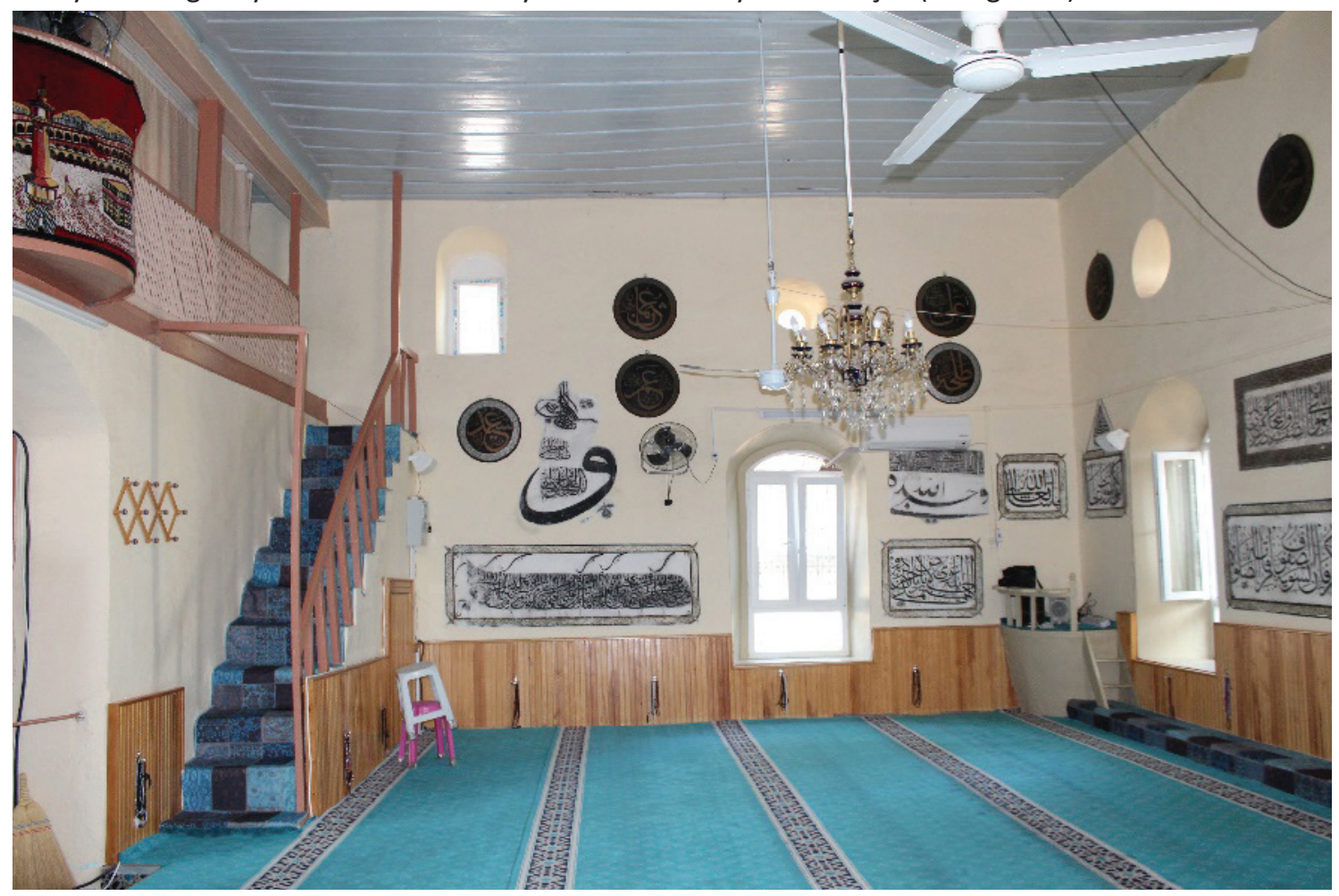

Fotoğraf 9. Harim doğu duvarına bakış.

Doğu duvarında pencerenin kadınlar mahfili tarafinda, kuzeydoğu köşede altta dikdörtgen çerçeve içerisinde, celî divânî istifli hatla beyaz zemin üzerine, siyah boyayla yazılmış kitabe yer almaktadır. Yazıyı çevreleyen dikdörtgen çerçeve beyaz zemin üzerine siyah şeritli; çerçevenin içi ise altın yaldız renkli kıvrım dallardan oluşan bitkisel bezemelidir. Dikdörtgenin köşelerinde içe doğru alem şeklinde dört hilal motifi yerleştirilmiştir. Yapılan badana işleri sırasında yazıların üzeri yer yer beyaz boyayla tahrip edilmiştir. Özellikle kitabenin alt köşesindeki sanatçı imzası olduğu anlaşılan hat silinerek okunamaz hâle gelmiştir (Fotoğraf 10).

Kitabenin okunuşu şöyledir: “Tehassantü bi-zil mülki ve'l-melekûti ve aksemtü bi-zil ızzeti ve'l-Azameti ve'l-Kibri ve'l-Ceberrûti ve tevekkeltü alel hayyil kayyûm ellezî lâ yenâmü ve lâ yemût" şeklinde Tahassun duası ve "Subbûhun kuddûsun Rabbu'I-melâiketi ve'r-Rûh, Sadaka Resûlallah" hadisi yazılmıştır (Nevevî, ty: 42, 1431). Kitabenin anlamı şöyledir: "Ben kendimi mülkün ve kâinatta olan her şeyin sahibinin ellerine bıraktım. Ve ben, çok yüce ve ulu, azametliye ve her şeyin sahibine sığındım. Ve kendisinde bir eksiklik olmayan, ölümsüz, hep diri olana güvendim. O tüm noksanlıklardan münezzeh, mukaddes, meleklerin ve Ruh'un (Cebrail) Rabbidir" ve "Allah'ın Elçisi doğru söyledi". Yazıımıştr. ${ }^{2}$

Metinde yazan Tahassun duası kazalardan ve belalardan korunmak için okunmaktadır. Duayı sürekli olarak sabah ve akşam çevresine yedi kere okuyup, üfleyerek kendini daire içerisine alan kişinin Allah tarafindan her türlü kötülüklerden korunduğuna inanılmaktadır (illoğlu, ty: 904).

2 Kitabeyi Hikmet Zeyveli okumuş, tercümesini İlyas Yorulmaz yapmıştır. 
Doğu duvarında, kuzeydoğu köşede üst seviyede beyaz zemin üzerine siyah boyayla yazılmış, çerçevesiz, kitabeler bulunmaktadır. Çok sayıda kitabe büyük celî sülüs bir vav harfinin içine yerleştirilmiştir. Vav harfinin içinde istifli sülüs hatla Kalem Suresi, 4. Ayet yazılmıştır. Okunuşu ve anlamı şöyledir: "Ve inneke le'alâ hulukin azîm", "Ve gerçekten sen, büyük bir ahlak üzerindesin" (Kur’an, 2011: 636). Kalem Suresi, 4. Ayet'in üzerinde sülüs hatla "Sadakallâhulazim" yani "Azim olan Allah doğruyu söyledi”" yazılmıştır (Fotoğraf 11).

En üstte beyaz zemin üzerine, siyah boya ile tuğra yazılmış hat içerisinde "Şefâ’at̂́ li-ehli'l-kebairi min ümmet̂́” yani "Benim şefaatim ümmetimden büyük günah işleyenleredir" (Sünen-i Tirmizi, 2004: 2435). Hadisi ile bu yazının kuzeyinde "Gâle'n-nebiyyü aleyhi's-selam”, "Peygamber (nebi) dedi, ona, selam olsun" yazıımıştır. Sanatçı tuğranın altında ise "ketebehü Hüseyin Avni" şeklinde sanatçı imzasını ve kitabeleri yazdığı "1330" yılını belirtmiştir (Fotoğraf 11).

Hattat bütün bu yazdıklarının belgesi şeklinde kitabelerin yazım tarihini ve kendi ismini büyük vav harfinin altına bir kez daha eklemiştir. Burada Arapça rakamlarla "1330" ve dîvânî hat, armudi istifle "ketebehü Hüseyin Avni" şeklinde sanatçı imzasına rastlanmıştır. (Fotoğraf 11). Buradaki yazılar da beyaz badana ile boyandığından yazıtlara okunamayacak kadar zarar verilmiştir.

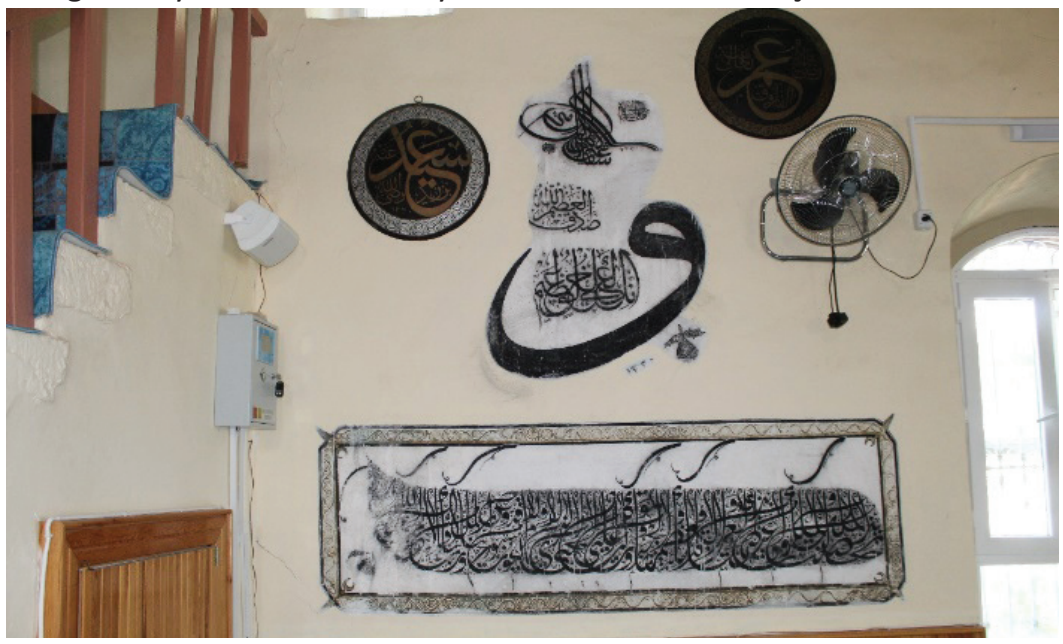

Fotoğraf 10. Doğu duvarında, kuzeydoğu köşede bulunan kitabeler.

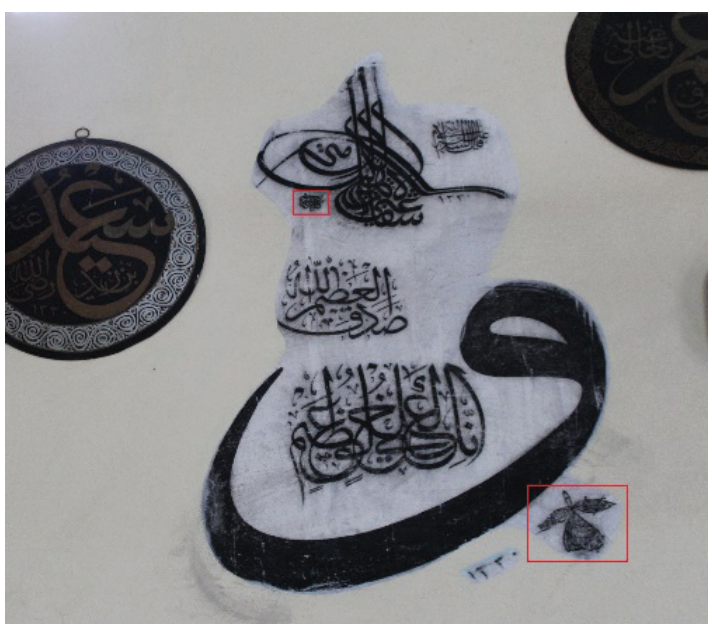

Fotoğraf 11. Doğu duvarı kuzeydoğu köşede üst sıra; vav harfinin içinde ve üstünde ayet ve tuğralı hadis, vav harfinin altında ise 1330 tarihi ve Hüseyin Avni ketebeli armudi istif. 
Doğu duvarının güneydoğu köşesinde iki sıra halinde kitabeler bulunmaktadır. Alt sırada beyaz zemin üzerinde, dikdörtgen çerçeve içerisinde siyah boyalı, sülüs istifli kitabe yer almaktadır. Çerçevenin içi altın yaldız renkli kıvrım dallarla doldurulmuştur. Türkçe olarak "Ya İlahi cehennemden eyle bizi halas, Ya Rahim, Ya Kerim" şeklinde dua metni yazılmıştr. Kitabe metninin altında "ketebehü Hüseyin Avni" imzasına ve "1329" tarihine rastlanmaktadır (Fotoğraf 12).

Doğu duvarının güneydoğu köşesi üst sırasında, güneyde kare çerçeve içinde; beyaz zemin üzerine siyah boya ve celî sülüs istifle "Mâşâallah Teâla" yani "Yüceler Yücesi Allah dilerse” yazılmıştır. Kare çerçevenin içi altın yaldız renkli kıvrım dal bezemeyle doldurulmuştur (Fotoğraf 12).

Mevcut kitabenin kuzeyinde birbirine bitişik iki farklı kitabe daha görülmektedir. Her ikisi de beyaz zemin üzerine siyah boyayla yazılmıştr. Alttaki kitabe çerçevesiz ve celî sülüs hatla "Ya Vahdetullah" yani "Ey bir Allah" yazıımıştr. Bu kitabenin üzerinde ise celî kûfi istifli hat bulunan kitabe yer almıştır. Kitabenin baş tarafinda Enbiya Suresi, 87. Ayetin bir kısmı "Lâ ilâhe illâ ente subhâneke innî küntü mine'z-zâlimîn, Sadekallahulazîm.", "Senden başka ilah yoktur, Sen tüm noksanlıklardan yücesin. Gerçekten ben, zalimlerden oldum. Azim olan Allah doğruyu söyledi." (Kur’an, 2011: 360) yazılmıştr. Kitabenin sonunda ise "Kâle'llâhu Teâlâ fi'l Kur'ân'il kerîm ve'n-nebiyyu'I-kerim"³ yazılmıştr. Maalesef yazının tam üzerine konulan klima ünitesi harflerin bir kısmının üzerini kapatarak yazılara zarar vermekte ve okunmasını güçleştirmektedir (Fotoğraf 12).

Yûnus (as) peygamberin kıssasının verildiği ayette inananların arzularının hemen olmaması durumunda ümitsizliğe kapılmamaları ve sabretmelerinin fazileti anlatılmaktadır. Kur'an'a göre Yûnus (as) kavmi kendisini inkâr edince onlardan kaçarak, Allah'tan izinsiz görevini terk etmiş, yükle dolu bir gemiye binmiştir. Geminin batma tehlikesi geçirmesi üzerine yolculardan birisinin denize atılması için çekilen kura, Yûnus'a (as) çıkmış ve denize atılarak bir balık tarafindan yutulmuştur. Sonra hatasını anlamış "Senden başka ilâh yoktur, şüphesiz ben zalimlerden oldum." diyerek Allah'tan af dilemiştir. Allah tarafindan duasının kabul edilmesiyle güçsüz bir halde balığın karnından sahile çıkarılarak kurtarılmıştır (Harman, 2013: 598).

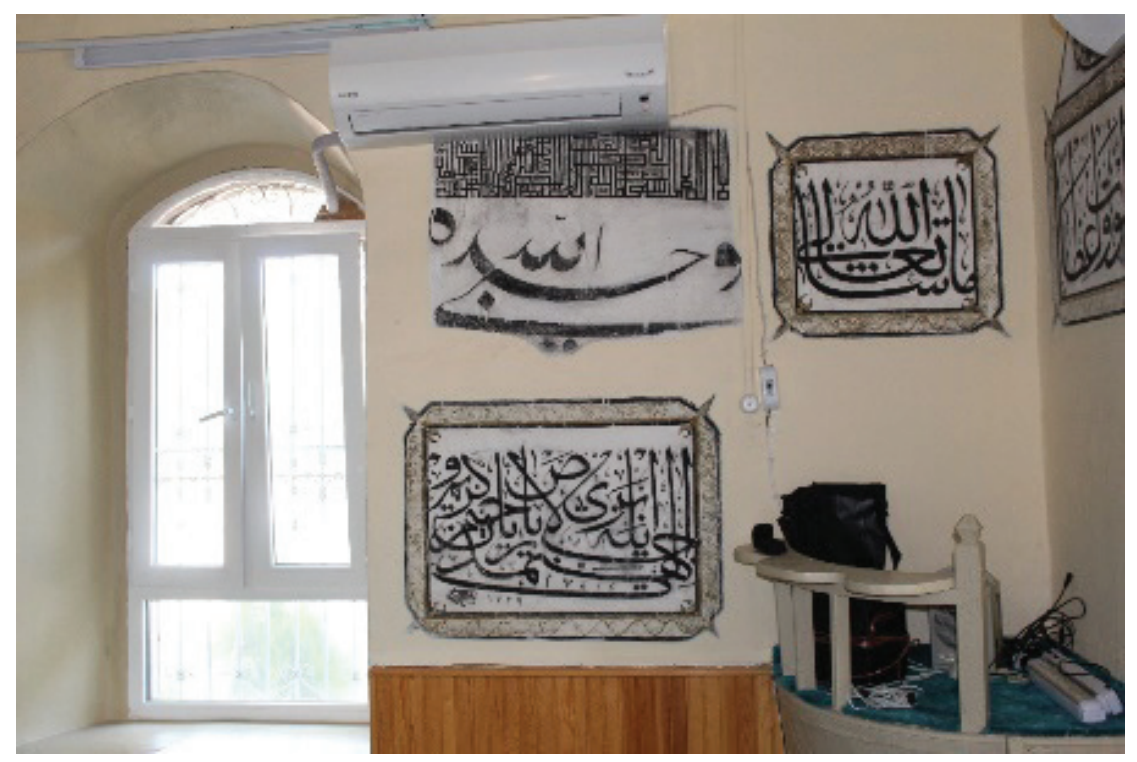

Fotoğraf 12. Doğu duvarında, güney doğu köşede bulunan kitabeler.

3 Kitabe Ankara Üniversitesi, Illahiyat Fakültesi İslam Tarihi ve Sanatları Bölümü öğretim üyesi Prof. Dr. Abdülkadir Dündar ve Yalova Üniversitesi İslami İlimler Fakültesi öğretim üyesi Doç. Dr. Süleyman Berk tarafindan okunmuştur. Okuması oldukça güç kitabeyi okuyarak sağladıkları destek ve yardım için kendilerine teşekkürlerimi sunarım. 
Caminin güney duvarında, eksenin merkezinde yuvarlak nişli mihrap; mihrabın doğusunda ve batısında çift sıralı pencere düzeni uygulanmıştr. Alt seviyede dikdörtgen biçimli ve yuvarlak kemerli iki pencere yer alırken, üst sırada, alt pencerelerin hizasında iki gül pencere açılmıştır. Mihrap, alçı malzemeden, tonoz kavsaralı ve yarım daire formlu nişe sahiptir. Mihrabın kavsara kuşatma kemeri yuvarlak formludur ve mihrap kalınca bir silme ile ters $U$ şeklinde çevrelenmiştir. Mihraba atfedilen kutsiyetler nedeniyle, gökyüzüne açılan bir pencere gibi düşünülmüş ve nişin içine -adeta bir pencere perdesi gibi- yerleştirilmiş kalem işi tekniğinde püsküllü perde motifiyle tamamlanmıştır. Perde motifi aşağıya doğru sarkan üç boğumludur ve her boğumun içi istifli hatlarla doldurulmuştur. Kıble duvarının güneydoğu köşesinde ahşap korkuluklu vaaz kürsüsü, güneybatısında da ahşaptan sade ancak camiyle uyumlu minber bulunmaktadır. Her ikisi de özgündür (Fotoğraf 13, 31).

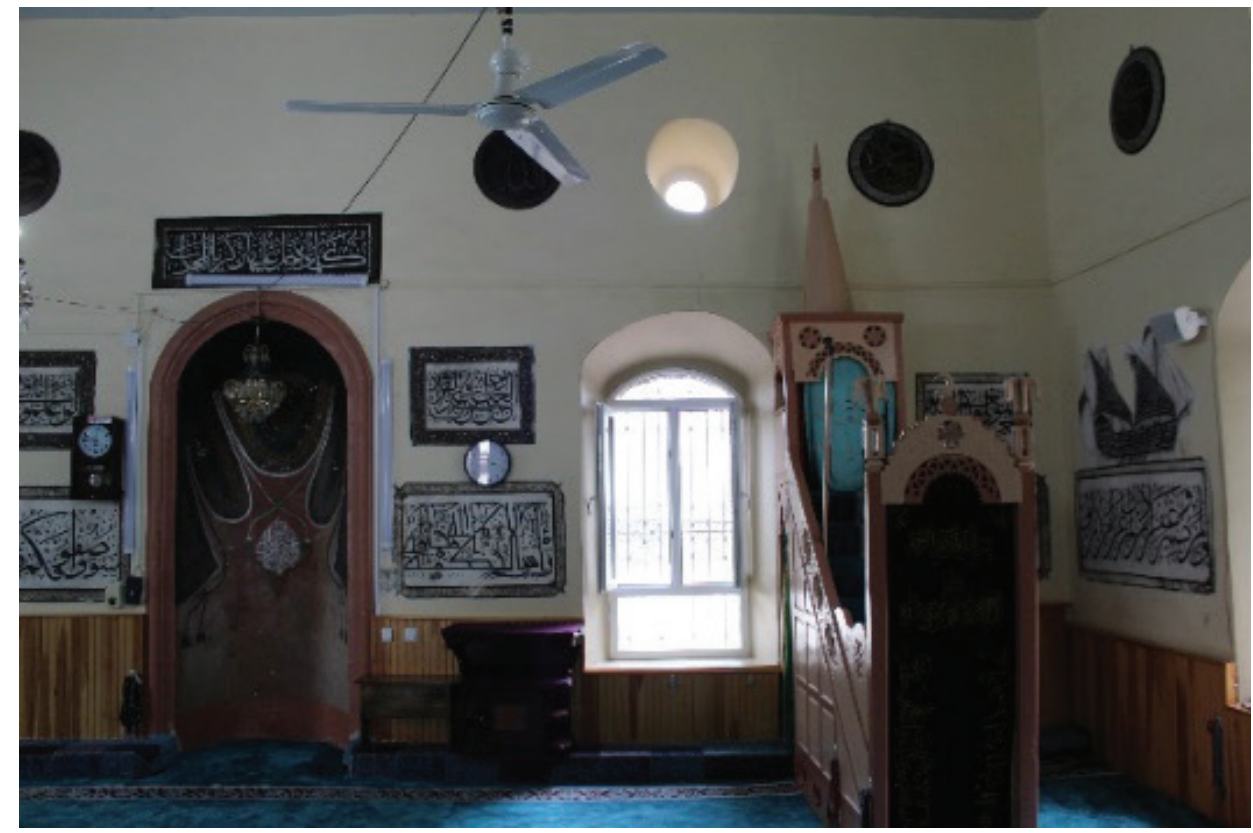

Fotoğraf 13. Mihrap duvarına bakış.

Mihrap duvarı adeta bir tablo gibi boydan boya kitabelerle doldurulmuştur. Böylece kitabelerle zenginleştirilen güney duvarına mihrap nişi ve yazılarının da eklenmesiyle yapıya hareketlilik kazandırılmıştır (Fotoğraf 13).

Mihrabın kavsara alınlığında yaldız renkli, kıvrım dal bitkisel bezemeli bir kuşakla çevrelenmiş, dikdörtgen çerçeveli kitabe yer almaktadır. "1329" tarihinin ve "ketebehü Hüseyin Avni" imzasının bulunduğu celî sülüs hatlı kitabe içinde Mihrap Ayeti olarak bilinen, Ali İmran Suresi 37. Ayet'in içinde mihrap geçen “Kullemâ dehake 'aleyhâ Zekeriyyâ'l-mihrâb." yani "Zekeriyya onun yanına mihraba (mağbede) her girdiğinde." kısmı yazılıdır (Kur’an, 2011: 63) (Fotoğraf 14). Yazıların üzerinden beyaz kimyasal boya ile geçilerek yazılar tahrip edilmiştir. Altın yaldız rengindeki sanatçı imzası ve yazım tarihi üzerindeki boyalara dokunulmamış, boyanmış yazıların altından da özgün olan altın yaldızlı renkler seçilebilmektedir. Özgün durumunda olanların altın yaldız renginde boyayla yapıldığı bellidir.

Mihrap nişinin kavsarasında perde motifinin aşağıya doğru sarkan ilk boğumunda; koyu mavi zemin üzerine altın yaldızla, celî sülüs istifli çerçevesiz yazıda "Sübhâneke mâ abednâke Hakkun ibâdetike yâ Ma'bûd.", "Ey kulluk edilmeye en layık olan Allah `m sana hakkıla ibadet edemedik." anlamına gelen dua yazılıdır (Fotoğraf 15). Bu yazının altında yine mavi zemin üzeri, altın yaldızla celî sülüs istif hatta 
Yunt Dağı Karakılınçıı Köyü Camii’nde Yazının Bezeme Unsuru Olarak Kullanımı ve Yapının Mimari Analizi

Raman Suresi 26. ve 27. Ayetler "Kullu men aleyhâ fâni." ve "yebkâ vechu Rabbike żû-I Celâli ve'l-ikrâm." yazılmıştrr. Anlamı: "Yeryüzünde bulunan her canlı ölümlüdür. Ancak yüce kudret ve ikram sahibi Rabbinin kendisi ise bakidir." (Kur’an, 2011: 595) anlamını taşımaktadır (Fotoğraf 16).

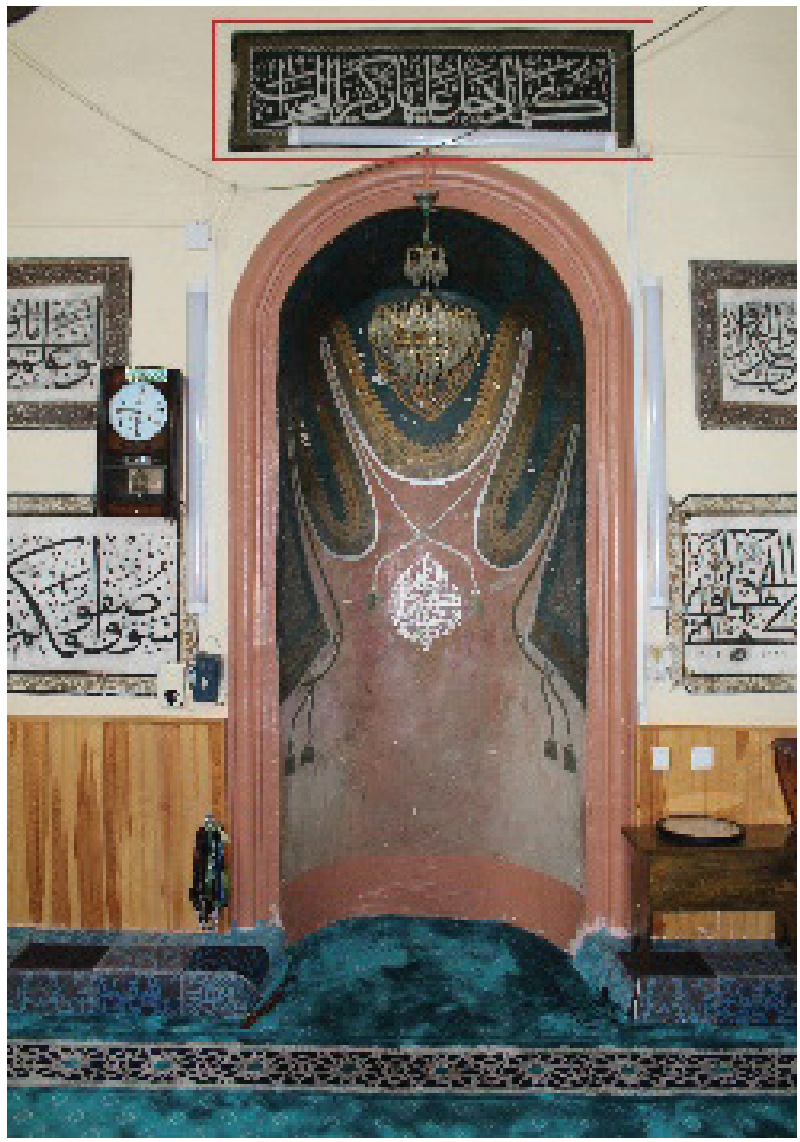

Fotoğraf 14. Mihraba bakış.

Mihrap nişinin ortasında pembe zemin üzerinde palmet şeklinde, stilize hayat ağacı motifli, celî sülüs istif hatta Hicr Suresi, 99. Ayet yazılmıştr. "Va'bud Rabbeke hattâ ye'tiyeke-I yakîn.", "Ve sana ölüm gelinceye kadar Rabbine kulluk et." (Kur’an, 2011: 286) anlamına gelmektedir. Perdenin düğümleri de bu istife adeta çerçeve yapılmıştı (Fotoğraf 14,17). Yazının özgün halinde altın yaldız renginde olduğu boya altındaki kalıntllardan anlaşılmaktadır. Günümüzde ise gümüş renkli kimyasal bir boyayla yazının üzerinden tekrar geçilerek yazı bozulmuştur.

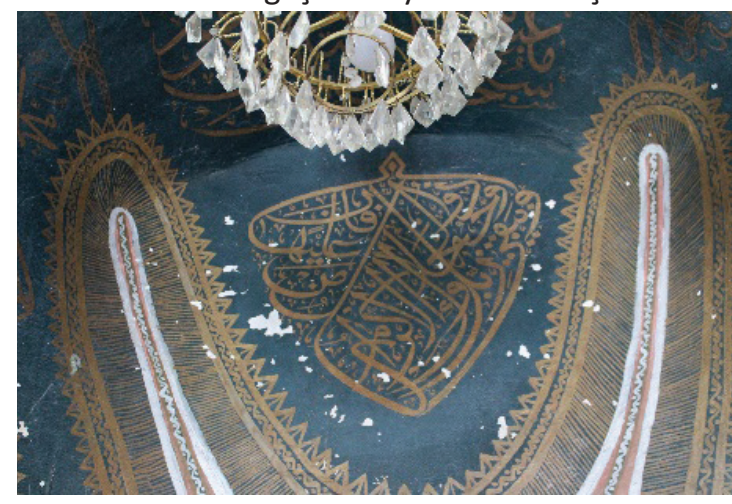

Fotoğraf 15. Mihrap kavsarasındaki yazı.

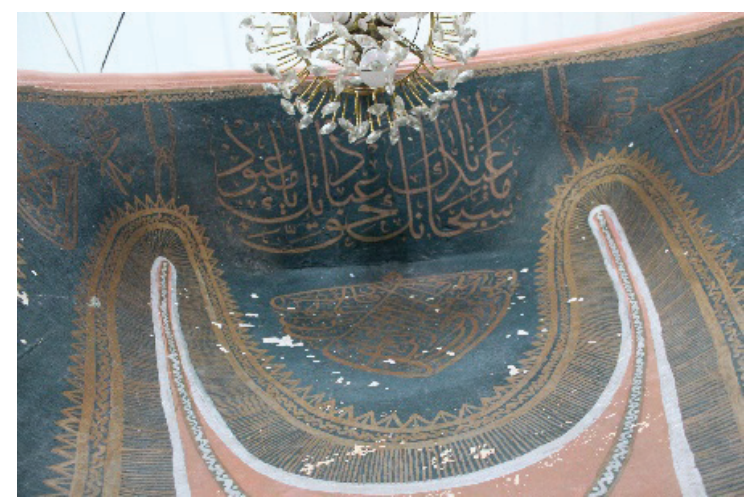

Fotoğraf 16. Mihrap kavsara altındaki yazı. 


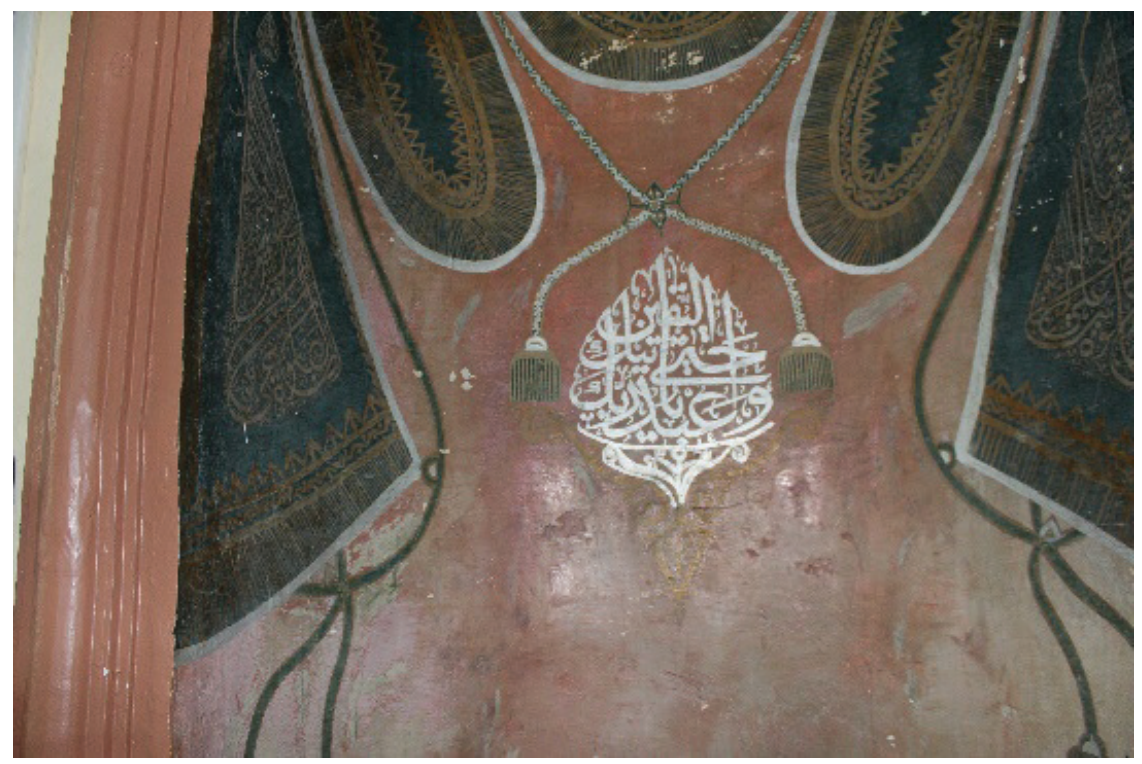

Fotoğraf 17. Mihrap nişinin ortasında stilize hayat ağacı motifi şeklinde celî sülüs istif.

Mihrap nişinde perdenin boğumları içinde, koyu mavi zemin üzerine, altın yaldız renginde vaaz kürsüsüne bakan tarafinda, damla istif sülüs hatla; "Ya Muyessirü'l-murâdat" "Ey muratları bahşeden”, minbere bakan tarafinda "Ya Dâ'vete'l-mucib”, "Ey dualara cevap veren” şeklinde Allah'ın sıfatları yer almıştır (Fotoğraf 18-19).
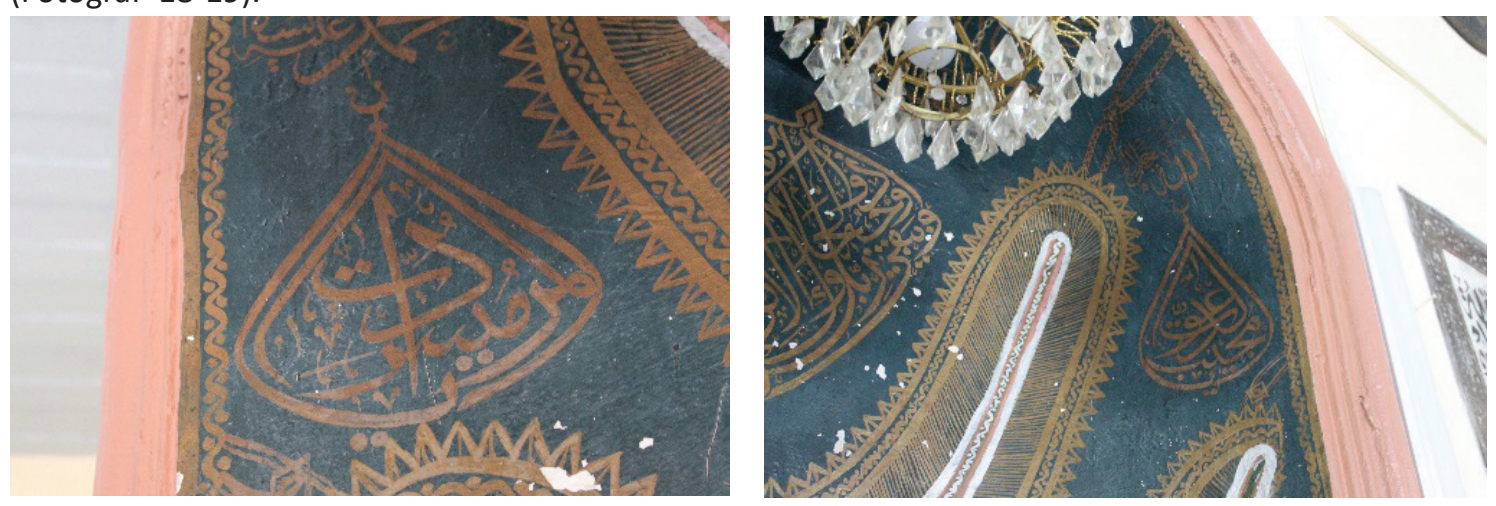

Fotoğraf 18, 19. Mihrab nişinin içinde yer alan damla istifli yazılar.

Mihrap nişinin vaaz kürsüsüne bakan tarafinda, perdenin üçgen kat içinde celî dîvânî istifli hatla Ankebût Suresi, 45. Ayetin bir bölümü; “Inne’s-salâte tenhâ ani'l-fahşâ-i ve'l-munkeri ve'l-eżikrullâhi ekber.”, "Şüphesiz namaz, kişiyi, hayâsızlıktan ve kötülüklerden alıkoyar." (Kur'an, 2011: 441-442) anlamına gelen kısmı yazılmıştır. Üstündeki damla istif dîvânî hatla yazılmış yazı ise "Sadakallâhulazim", "Azîm olan Allah doğru söyledi" şeklindedir (Fotoğraf 20).

Mihrap nişinin vaaz kürsüsüne bakan tarafinda da, perdenin üçgen kat içinde celî dîvânî istifli hatla Nisa Suresi, 103. Ayetin bir kısmı; “Inne’s-salâte kânet alâ'l-Müminîne kitâben mevkûtâ.", “Namaz, Mü’minler üzerine vakitlerle farz kılınmıştır." (Kur’an, 2011: 105) Anlamına gelen bölümü yazılmıştır. Üstündeki damla istif dîvânî hatla yazılmış yazıda ise "Sadakallâhulazim", "Azîm olan Allah doğru söyledi” yazmaktadır (Fotoğraf 21). Böylece namaz ayetleri yazılmak suretiyle inananlara namazı sürekli kılmaları öğütlenerek erdemli ve iyi insanlar olmaları amaçlanmıştır. 

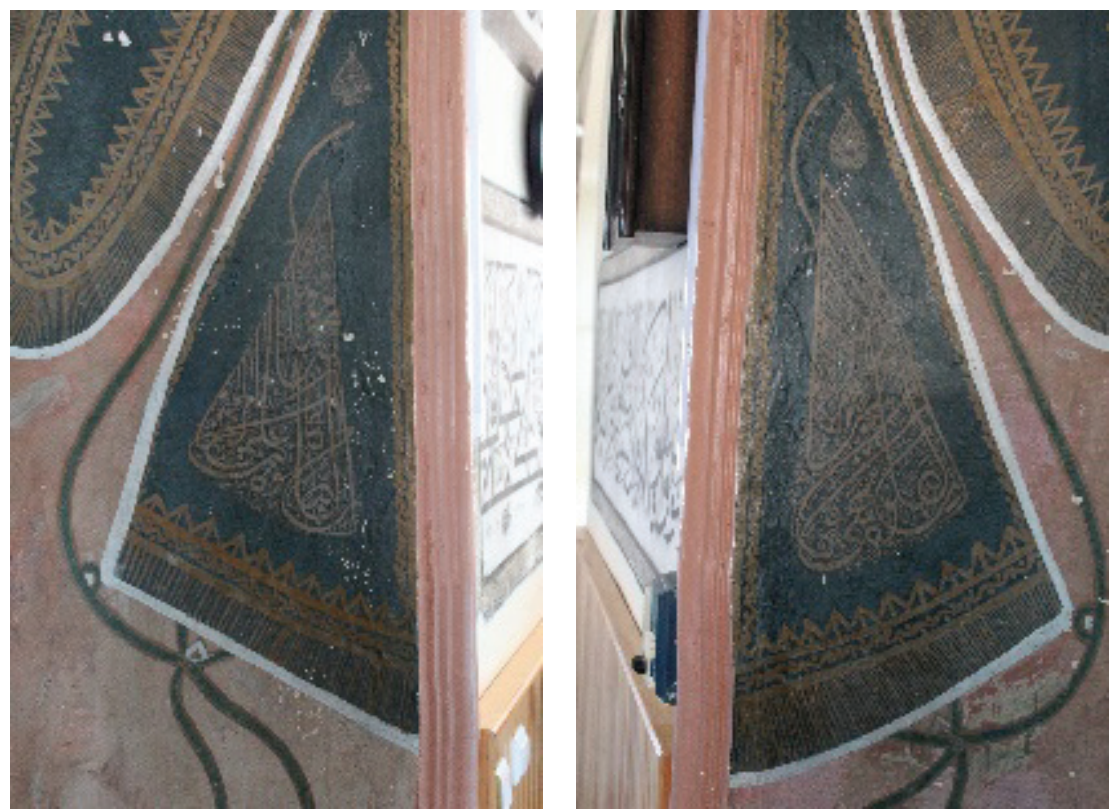

Fotoğraf 20, 21. Mihrap nişi perdesinde bulunan celî dîvânî istif yazılar.

Mihrap duvarının güney doğu köşesinde, vaaz kürsüsünün üzerinde altlı, üstlü iki kitabe karşımıza çıkar. Üstte siyah boyalı üçgen çerçeve içinde, beyaz zemine siyah boyayla celî sülüs damla istif biçiminde "Limen Ya hazreti fahri âlem.", "Bütün âlemlerin övüncü onadır." anlamına gelen Hz. Muhammed’e (a.s) övgü yer alır. Yazının altında da sanatçı imzası "ketebehü Hüseyin Avni" ibaresi bulunur. Bu kitabenin altında ona bitişik şekilde siyah dikdörtgen çerçeveli ve çerçevenin içi altın yaldız renkli kıvrım dal süslemeyle doldurulmuş ve celî sülüs hatla yazılmış "Kefâ bi'I-mevt vaizan.", "Nasihatçi olarak ölüm yeter." anlamına gelen bir kitabe daha göze çarpar (Fotoğraf 22).

Mihrap duvarının vaaz kürsüsü tarafinda, mihrap ve pencere arasında iki sıra halinde dikdörtgen çerçeveli iki kitabe görülür. Kitabelerde Hz. Muhammed'in (a.s) namaz kılarken saf tutmanın önemini belirttiği hadisleri yer alır. Üst sıradaki kitabe çerçevesinin içi siyah zemin üzerine koyu kahverengi kıvrım dal süslemeyle doldurulmuş; altında "1330" tarihi ve sanatçı imzası "ketebehü Hüseyin Avni" ibaresi yazıımıştır. Çerçevedeki özgün boyalı kıvrım dalların ucuna yakın zamanda anlamsız beyaz noktalar konularak, süslemeye zarar verilmiştir. Diğer yazıtta ise beyaz zemine, siyah celî sülüs istifle "Lev alimu mafi's-saffil evveli le tehârebu Sadega Nebiyyullah.", "ilk safların sevabını bilseydiniz, mutlaka kura çekerdiniz." (Sünen-i Tirmizi, 2004: 225) hadisi ve "Allah’ın nebisi doğruyu söyledi" ibaresi yazılıdır (Fotoğraf 23).

Bu kitabenin altında ondan daha büyük beyaz zemine, altın yaldız renkli kıvrım dal dolgulu çerçeveli ve "1329" tarihi ile "ketebehü Hüseyin Avni" imzalı bir kitabe daha yer alır. Kitabe beyaz zemin üzerine siyah celî sülüs istifli hatla "Savvu sufufeküm feinne tesviyeti's-sufufî min igameti's-salatî., "Safları düzeltin. Bu namazın doğru kııındığını gösterir." (Sünen-i Tirmizi, 2004: 227) anlamındaki hadis yazıIı kitabeye rastlanır (Fotoğraf 23). Hz. Muhammed'in (as) cemaatle kılınan namazlarda saf düzenine özen gösterdiği, namaza başlamadan önce daima safları düzelttiği ve saf düzeninin bozuk olması halinde namaz kılanların arasına Allah tarafindan düşünce ve fikirlerinde ayrılıklar sokulacağı beyan edilmiştir (Sünen-i Tirmizi, 2004: 224-228). Ayrıca çeşitli hadislerden rivayetle ilk safta veya saflarda namaz kılanların Allah’ın rahmetine ve meleklerin duasına mazhar olacağına inanılmaktadır (Öğüt, 2008: 435-436). Kitabelerin saf düzeninin sağlanması amacıyla yazıldığı anlaşılmaktadır. 

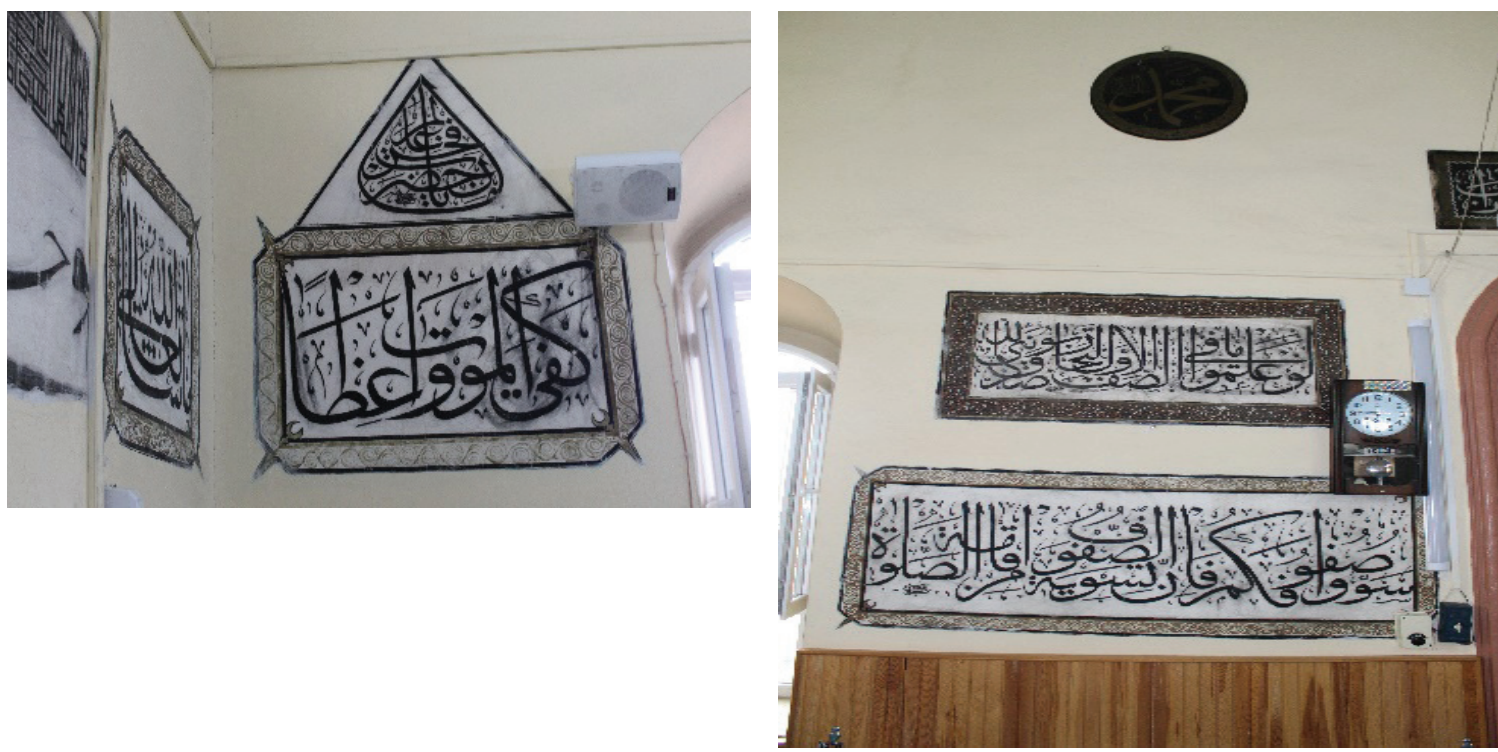

Fotoğraf 22, 23. Mihrap duvarının güneydoğu köşsesinde, üstte damla istifli; altta celî sülüs kitabe ile mihrap duvarının vaaz kürsüsü tarafinda, mihrap ve pencere arasında iki sıra halinde celî sülüs istif kitabeler.

Mihrap duvarının minber tarafinda, mihrap ve pencere arasında iki sıra halinde dikdörtgen çerçeveli iki kitabe karşımıza çıkar. Üstteki kitabe "1330" tarihli ve celî sülüs istiflidir. Yazının çerçevesine siyah zemin üzerine altın yaldız kıvrım dal süslemeyle dolgu yapılmıştı. Çerçevenin içerisindeki özgün boyalı kıvrım dallara beyaz boyayla noktalar eklenerek tahrip edilmiştir. Kitabe metninde "el-Cemaatü rahmetün ve'l-firkatü azabün.", "Birlikte rahmet ayrılıkta azap vardır." (Sünen-i Tirmizi, 2004: 2165) hadisi yazılmıştır (Fotoğraf 24). Alt sıradaki kitabede de, siyah ve altın yaldız kuşaklı dikdörtgen çerçeve içerisinde; beyaz zemine, altın yaldız renkli kıvrım dal bezeme dolgu yapılmıştır. Kitabenin altında "1329" ve "1327" yazım yıllarının verildiği iki tarih ile "ketebehü Hüseyin Avni" yazılı sanatçı imzası bulunmaktadır. Kitabenin metninde çiçekli celî kûfi istif hatla "Re'sül hikmeti mehafetullah.", "Hikmetin başı Allah korkusudur." anlamındaki öğüt yazıımıştır (fofo 25).
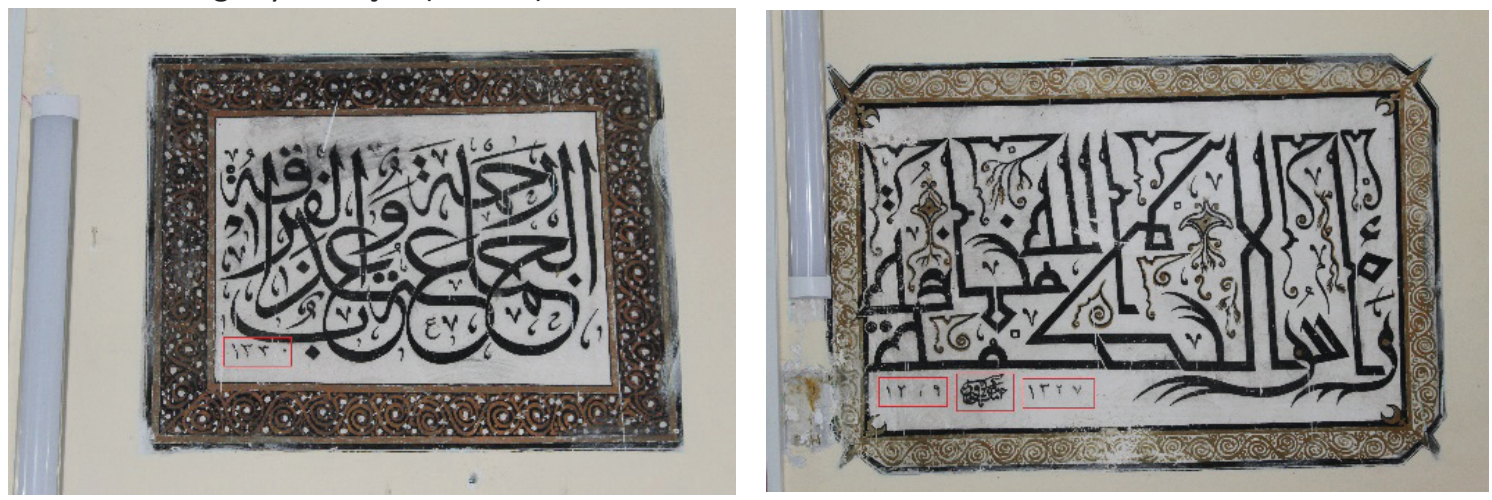

Fotoğraf 24, 25. "1330" tarihli ve celî sülüs istifli kitabe ve "1329" ve "1327" yıllarının verildiği iki tarih ile "Hüseyin Avni" ketebeli çiçekli celî kûfi istifli hat.

Mihrap duvarının güneybat köşesinde iki sıra halinde dikdörtgen çerçeveli celî sülüs istifli iki kitabe görülür. Her iki kitabe de de beyaz zemin üzerine, siyah şeritlerle çerçeve oluşturulmuş; çerçevelerin içi de altın yaldız, kıvrım dal bitkisel süslemeyle bezenmiştir. Kitabelerde Al-i İmran Suresi 173. Ayetin bir

$$
\text { are } 271
$$


bölümü yer almaktadır. Altta "Hasbunallahu ve ni'mel vekil.", üstte ise ayetin devamı "ni'mel Mevla ve ni'me'n-nasîr.", "Allah bize yeter, O ne güzel vekildir." (Kur’an, 2011: 81) ayeti yazılmıştr. Üstteki kitabede "ketebehü Hüseyin Avni” imzası ve kitabenin yazım yılı olarak da "1330" tarihi bulunmaktadır (Fotoğraf 26).

Bu ayetle cemaate insanlardan değil yalnızca Allah'tan korkulması gerektiği, sadece Allah'tan korkanlara ise Allah'tan bir nimet ve lütuf olarak hiçbir kötülüğün dokunamayacağı öğütleri verilmektedir.

Harimin batı duvarı da, doğu duvarında olduğu gibi iki sıralı pencere düzenindedir. Alt sırada bir dikdörtgen, üst sırada ise bir gül, bir de dikdörtgen olmak üzere iki pencereye sahiptir. Batı duvarı da boydan boya istiflenmiş hat örnekleriyle bezenmiştir (Fotoğraf 27).

Batı duvarının güneybat köşesinde iki sıra halinde kitabeler bulunmaktadır. Alt sıradaki kitabe dikdörtgen çerçevelidir. Çerçevenin içinde beyaz zemin üzerine, altın yaldız kıvrım dallar dolgu malzemesi olarak kullanılmıştır. Çerçeve şeritlerinin neredeyse tamamı beyaz badana ile tahrip edilmiştir. Çerçevenin içinde beyaz zemine, siyah boyayla yazıımış, celî sülüs istif hat yer almıştır. Yazıtta Şûrâ Suresi, 43. Ayet yer alır. "Velemen sabera ve ġafera inne żâlike lemin azmi'I-umûr.", "Kim sabreder ve bağışlarsa bunu yapan işlerin en kararlısını yapmıştr." (Kur’an, 2011: 538) anlamına gelmektedir (Fotoğraf 28).

Üstte yer alan kitabe ise beyaz zemin üzerine, siyah boyayla ve celî sülüs istifli bir hatla yazılmış, Yedi Uyurlar (Ashab-ı Kehf) motifli gemi (sefine) resmidir. Geminin ön güverteye bakan birinci yelkeninde "Ya malikü'l-mülk, el-Cabbar", "Ey mülkün ebedi sahibi, gücü sınırsız"; ikinci yelkeninde Fetih Suresi, 1. Ayet "Innâ fetahnâ leke fethan mubînâ.", "Şüphe yok ki biz, sana apaçık bir fetih vermişizdir." (Kur’an, 2011: 566) ayeti yazılmıştır. Geminin ana gövdesinde celî sülüs istifle sağdan sola doğru Yedi Uyurlar ile köpeklerinin isimleri: "Yemlîhâ, Mekselînâ, Mislînâ, Mernûş, Debernûş, Şâzenûş, Kefeştatayyûş ve Kıtmîr" yazılmıştır (Fotoğraf 28).

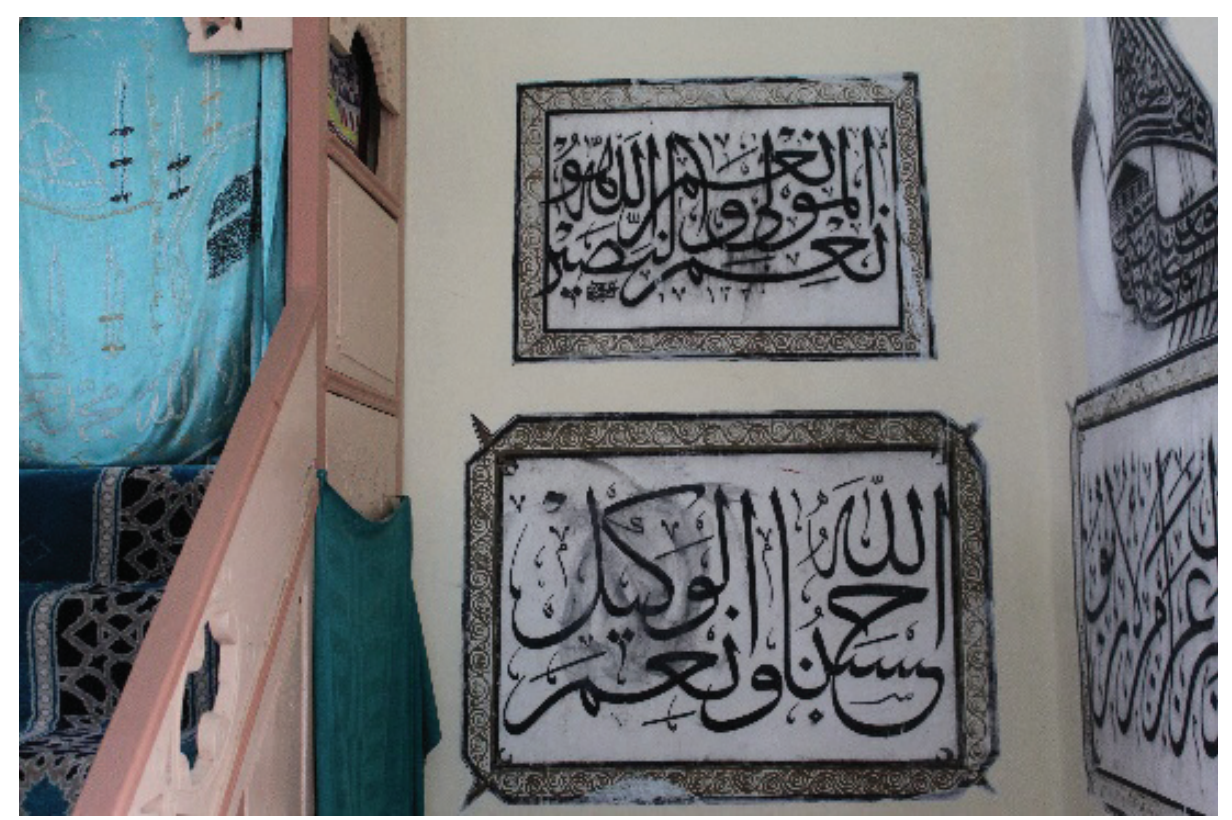

Fotoğraf 26. Mihrap duvarının güney-bat köşesinde iki sıra halinde dikdörtgen çerçeveli celî sülüs istifli kitabeler. 
Ramazan Uykur

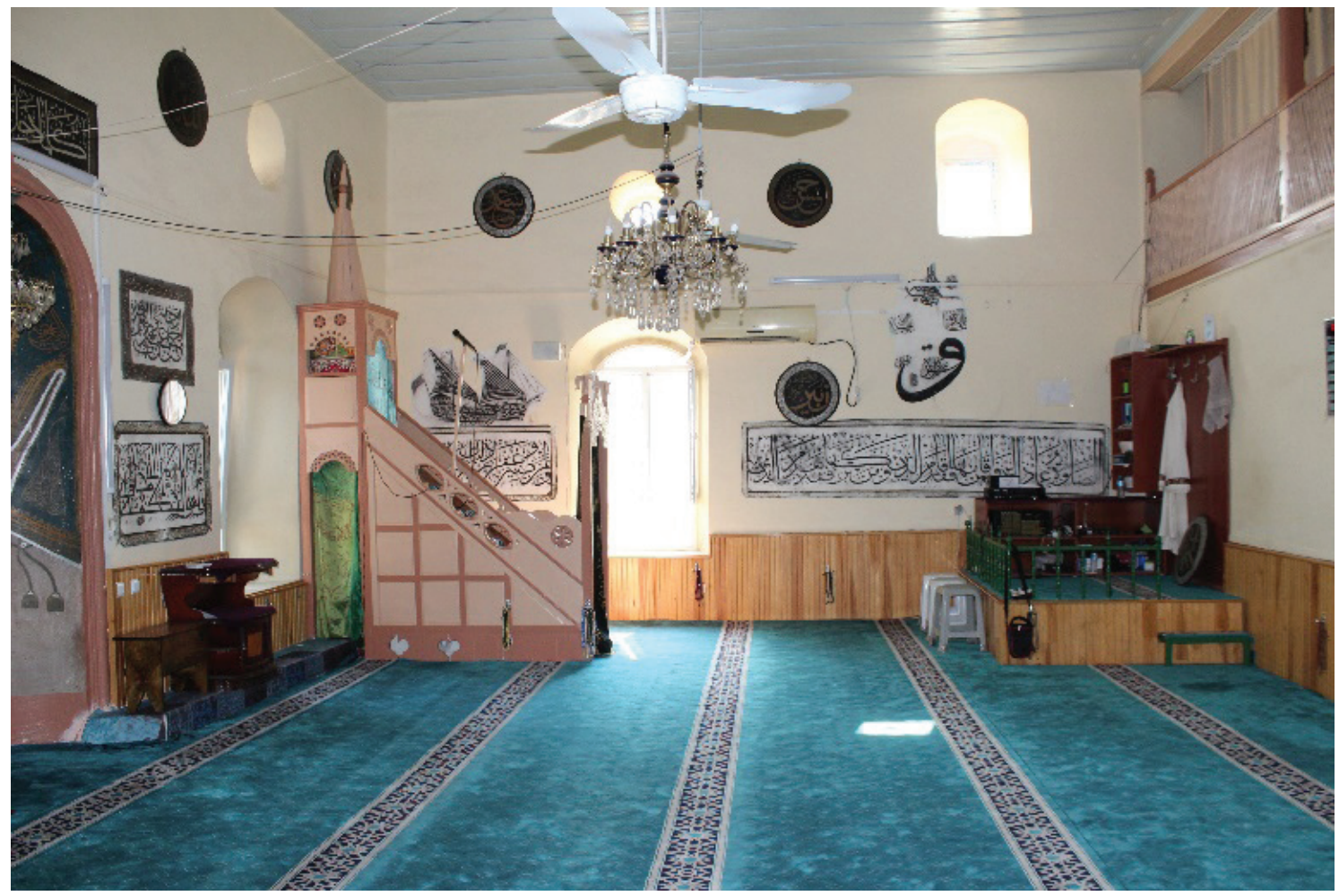

Fotoğraf 27. Harim bat duvarına bakış.

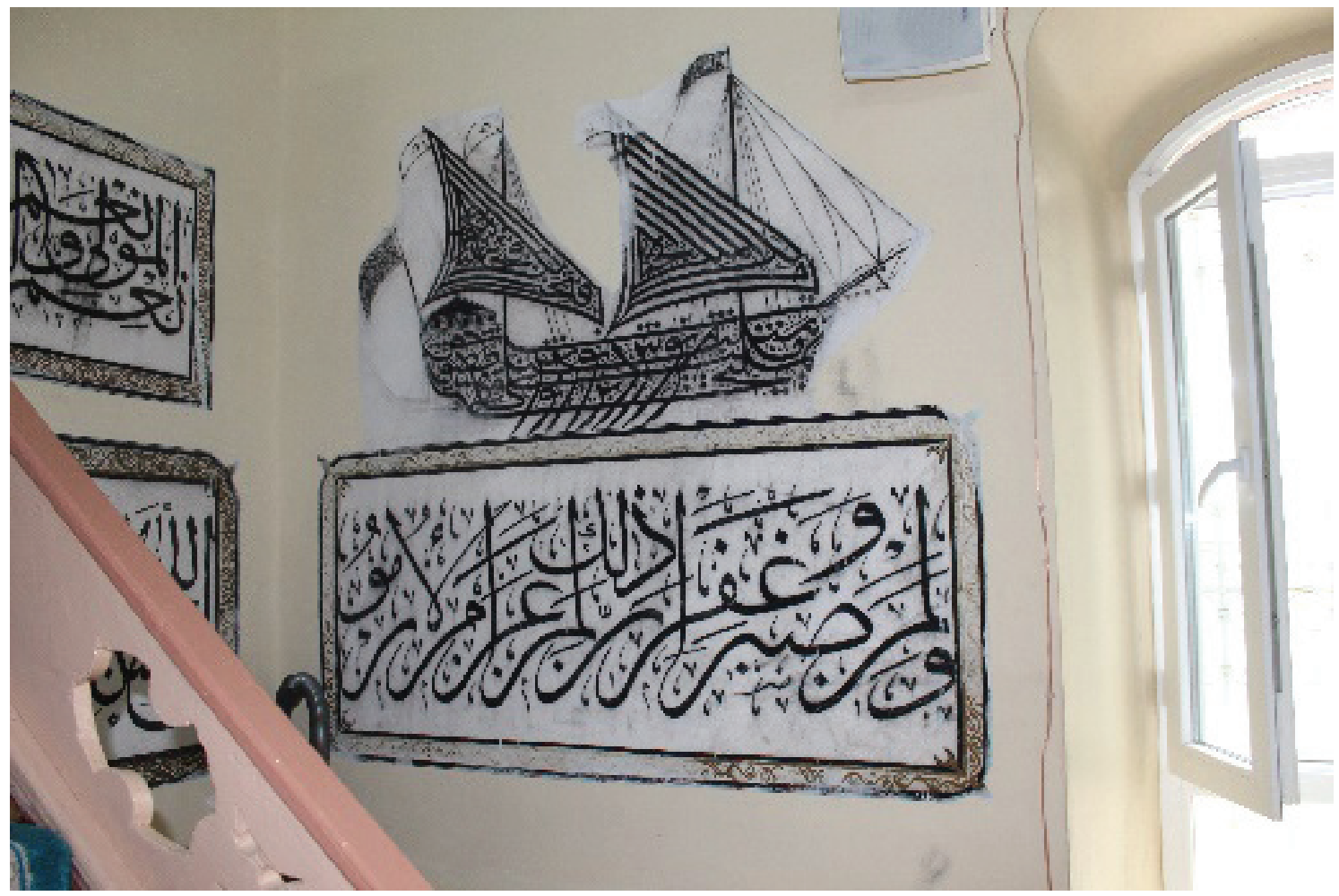

Fotoğraf 28. Bat duvarının güneybatı köşesinde alt sırada celî sülüs istif; üstte ise Yedi Uyurlar istifli yelkenli gemi resmi. 
Batı duvarının kuzeybatı köşesinde iki sıralı kitabe düzeni görülür. Alt sırada oldukça büyük dikdörtgen bir pano içinde "1328" tarihli kitabe yer almıştı. Kitabe siyah ve altın yaldızlı çift şerit şeklinde bir çerçeveye sahiptir; çerçevenin içi yine altın yaldızlı kıvrım dal süslemeyle dolguludur. Kitabe metni celî sülüs istifli bir hatla yazılmıştr. Kitabe metninde “Es-Salatü imadü'd-din men feikemaha fekat egame'd-din vementerkeha fekat hedeme'd-din.", "Namaz dinin direğidir. Kim onu kılarsa dinini ayakta tutar ve her kim onu terk ederse dinini yıkmış olur." (Yaşaroğlu, 2006: 356) anlamına gelen hadis yazılmıştır (Fotoğraf 29).

Batı duvarının kuzeybat köşesinde üst sırada beyaz zemin üzerine, siyah boyayla çerçevesiz yerleştirilmiş kitabeler mevcuttur. En üstte sülüs hatlı ve tuğra istifli Besmele "Bismillâhirrahmânirrahîm", besmelenin altında "ketebehü Hüseyin Avni" şeklinde sanatçı imzası ile "1328" olarak yazım tarihi yer almıştır. Besmelenin altında ve merkeze konmuş büyük bir vav harfinin arasında, istifli celî sülüs hat ile Mülk Suresi, 1. Ayet yukarıdan aşağıya doğru sıralanmıştr. Besmelenin sağında; "Tebârake'l-leżi”", solunda "biyedihi'I-mülk", vav ile birlikte kuyruğunda "ve hüve", vavın içinde "alâ kulli şeyin kadîr", ve "Sadakallahül âzim" yazılıdır. Ayetin metni şöyledir: "Tebârake'I-leżî biyedihi'I-mülk ve huve 'alâ kulli şeyin kadîr." Ayetin Türkçe meali de "Hükümranlığın sahibi olan Allah, yüceler yücesidir ve O’nun gücü her şeye yeter." (Kur’an, 2011: 633) “Azim olan Allah doğruyu söyledi.” anlamına gelmektedir (Fotoğraf 30).

Bat duvarında da maalesef yazıların üzeri beyaz boyayla sıvanması nedeniyle özgün boyalar oldukça zarar görmüştür. Ayrıca bu cephe üzerine klima ünitesi takıımış ve yazıların üzerinden de kablolar geçirilmiştir.

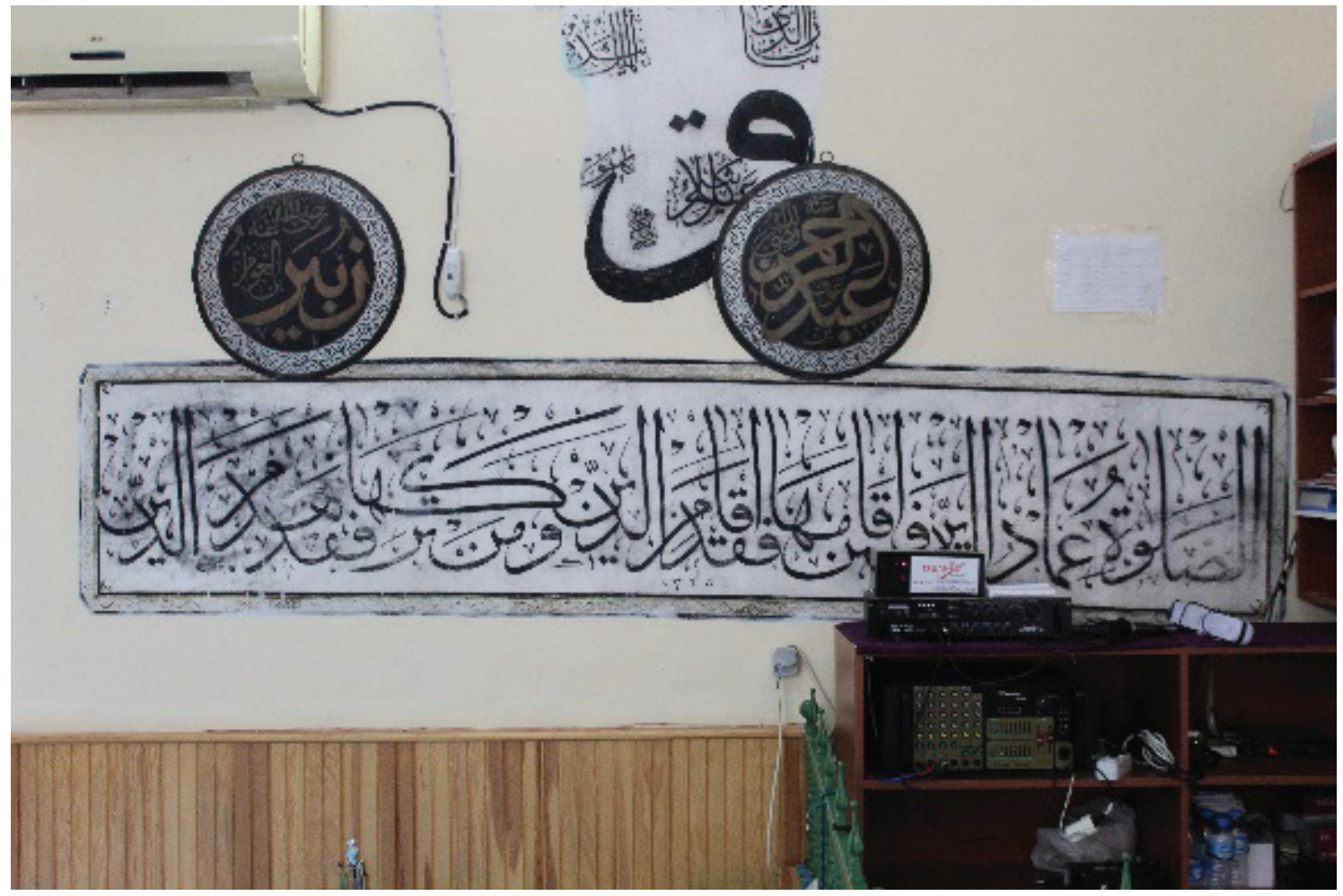

Fotoğraf 29. Harim batı duvarının kuzeybatı köşesinde alt sırada "1328" tarihli celî sülüs istifli kitabe.

4 Kitabe metni Hikmet Zeyveli tarafindan okunmuştur. 
Mihrap ile bat duvarı arasında yapının ahşap minberi bulunmaktadır. Minber sade, korkuluklarında ve süpürgeliklerinde ajur tekniği uygulanmıştır. Minber sade olmasına rağmen yapıyla uyumludur. Fakat üzeri açık, koyu pembe tonlarında yağlı boyayla boyanarak özgün rengi yok edilmiştir (Fotoğraf 31).
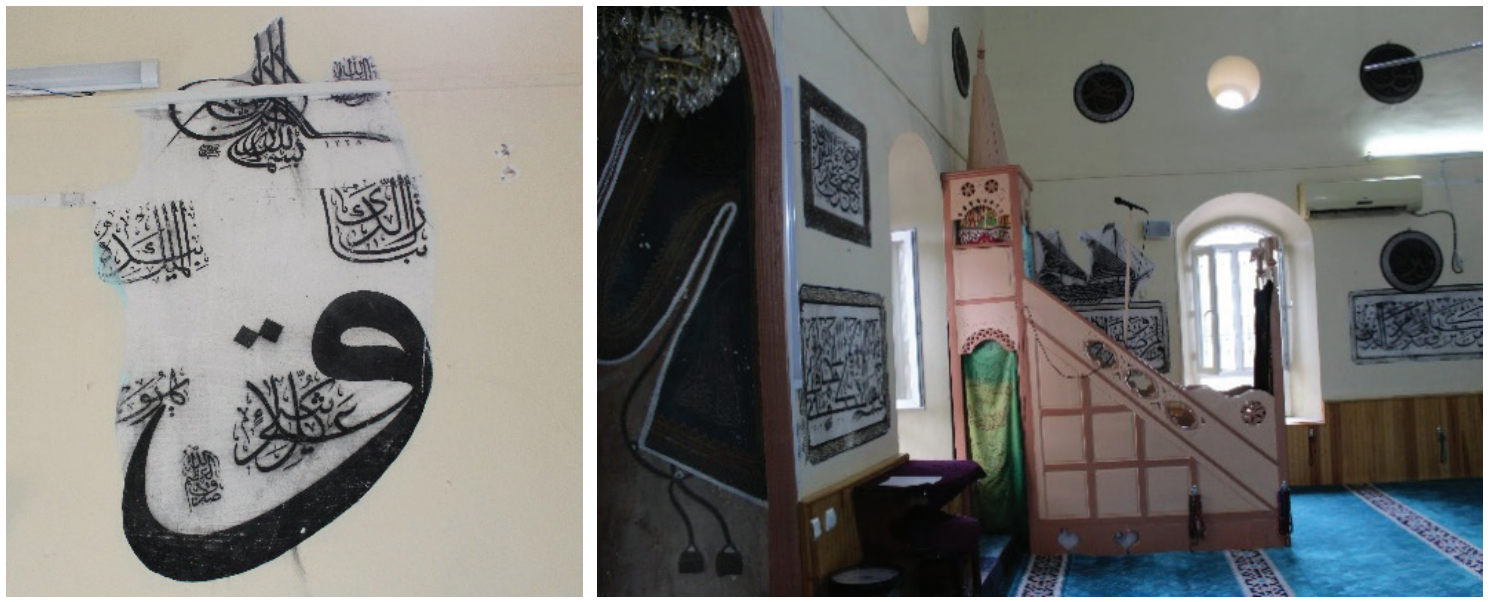

Fotoğraf 30, 31. Harim bat duvarı kuzeybat köşede üst sırada celî sülüs istif yazı ve caminin ahşap minberi

\section{Karşılaştırma Ve Değerlendirme}

Karakılınçlı Köyü'nün çok yakınında Yeniceköy isimli dağ köyünde de benzer bir cami bulunmaktadır. İnşa kitabesine göre, 1319H./1901-02M. yılında imâr edilen Yeniceköy Camii ile bundan alt sene sonra inşa edilen Karakılınçlı Köyü Camii'nin plân kurguları, Gotik biçimi andıran taç kapıları, dikdörtgen ve gül pencere biçimleri ve taş örgü/kesim teknikleri, bu iki camiyi aynı ustaların yaptığına işaret etmektedir. Her iki camide de yuvarlak kemerli açıklıklarla son cemaat yerine, ardından Gotik form izlenimi veren taç kapı ile harime giriş sağlanır. İki yapı da mihrap duvarına göre enine dikdörtgen plânlı, tek sahınlı harim ile kuzey duvarına bitişik galeri katında kadınlar mahfilinden meydana gelmiştir. i̇ki yapının perde motifli mihrapları da benzerdir. Camilerin mihrapları iki yana açılmış, üç boğumlu perde motifi, her bir perde boğumu içine yazılmış hat örneklerinden meydana gelmiştir. Ayrıca cephelerde yapılara karakterini kazandıran baklava dilimli kesme taş örgü tasarımı iki eserde tamamen aynıdır. Üstelik benzerlik sadece yapıyla sınırlı da değildir. Her iki yapının hat yazıları, ahşap minberleri ve süsleme özellikleri bakımından oldukça benzerdir. Yeniceköy Camii'nin minber iş̧̧iliği ve süsleme kalitesi dahi yüksektir.

Hattat Hüseyin Avni, Karakılınçlı Köyü Camii'nin hat yazılarında çok yerde yazım tarihlerini vermiştir. Buna göre 1327H./1909-10M., 1328H./1910-11M., 1329H./1911M. ve 1330H./1911-12M. yılları arasında farklı zamanlarda yazıımış kitabeler mevcuttur. Bir bakıma Hattat Hüseyin Avni caminin yapıldığı 1325H./1907-10M. yılından iki yıl sonra yazım işine başlamış, 1330H./1911-12M. yılına kadar belli aralıklarla gelip, giderek yazma işini tamamlamıştır. Yeniceköy Camii'nin mihrap duvarında ise armudi istifle Hattat Hüseyin Avni ketebeli sanatçı imzasına ve 1339H./1920-21M. tarihli, zengin hat sanatyla dolu örneklerle karşıllaşılır.

Her iki caminin hat ustası Hüseyin Avni, Yenice Köy Camii'nin yazılarını, Karakıııçlı Köyü Camii yazıtlarından dokuz sene sonra 1339H./1920-21M. yılında yazmıştr. Yeniceköy Camii'nin istifli yazıları, yazı tekniğinin uygulanışı ve yazılı resim gibi uygulamaları daha ustaca yapılmıştır. Bu bağlamda, Hüseyin Avni'nin aradan geçen dokuz yıl süresinde hat tekniğini ve sanatını bir hayli geliştirdiği gözlenmektedir. Belki de büyük bir ustanın yanında çalışma firsatı bulmuş ve yeni imkânlar elde etmiştir. Yeniceköy Camii'nin 
Yunt Dağı Karakılınçı Köyü Camii’nde Yazının Bezeme Unsuru Olarak Kullanımı ve Yapının Mimari Analizi yazıları hakkında oldukça ayrıntılı bir çalışma, araştırmacı H. İ. Eryılmaz tarafindan yapılmıştır. Araştırmacının bulgularına göre, Hattat Hüseyin Avni'nin babasının ismi Mustafa'dır ve kendisi de Bursalı gezici bir sanatçıdır (Eryılmaz, 2018: 549). Osmanlı döneminde Anadolu’yu köy köy dolaşan duvar, ahşap ve hat sanatı ustalarının varlığı bilinmektedir. Bu sanatçılar, gezgin ustalar olarak tanınmaktadır. İki caminin hatlarını yazan Hüseyin Avni'nin de böyle bir sanatçı olduğu anlaşılmaktadır.

Karakılınçı Köyü Camii duvarlarında farklı çeşitlerini gördüğümüz, Hüsn-i hat istiflerinin en dikkat çekici olanı resimli yazı olarak bilinen Yedi Uyurlar gemisidir. Yazı istifli gemi resimleri hat sanatının ustalık gerektiren kolu olması sebebiyle oldukça rağbet gören bir türüdür. Bunlar Yedi Uyurlar ve bir onun kadar dikkat çeken Amentü gemileridir. Karakılınçlı Köyü ve Yeniceköy Camii'nde Yedi Uyurlar gemisini görmekteyiz.

Amentü gemisi, Kur'ân-ı Kerîm Ayetleri üzerine temellendirilmiş ve imanın esaslarını dile getiren metnin gemi veya kayık şeklinde istiflenmesinden oluşmuştur (Neumeier, 20013: 2). Hüseyin Avni, Yeniceköy Camii'nde Amentü Gemisi'ni de muntazam olarak resmetmiş̧tir (Eryılmaz, 2018: 555-556) (Fotoğraf 38). Yedi Uyurlar Makamı halk nezdinde yaygın olarak bilinir ve çok sayıda yerde mağarası olduğu iddia edilir. Bu mağaraları ziyaret edenlerin, dertlerine deva bulacaklarına inanılır. Yedi Uyurlar Hıristiyanlar tarafindan da kutsal sayılmışlar, (Sümer, 1989) hatta Hıristiyan kaynaklarına göre hadise Efes'te meydana gelmiştir (Ersöz, 1991: 465). Kehf Suresi'nde onlardan imanlı kullar şeklinde övgüyle söz ediliyor olması da Müslümanlar tarafindan sevilmelerinin sebeplerindendir. Fakat bu insanların sayıları ve isimleri hakkında Ayetlerde açıklama geçmez. Hatta Kehf Suresi, 22. Ayette "Karanlığa taş atarak, "Onlar üç kişiydiler, dördüncüsü köpekleriydi" derler. Bir kııım da "Onlar beş kişiydi, altıncısı köpekleriydi." derler. "Yediydiler, köpekleriyle sekiz" diyenler de vardır. De ki "Onların sayısını Rabbim bilir; başka bilen de pek azdır." Onun için bu konuda, açıkça belli olan şey dışında onlarla tartş̧ma ve onların hiçbirinden bir görüş isteme." (Kur'an, 2011: 318). Buyrulmakla insanların onların sayılarını ve isimlerini bilemeyecekleri ve bu konuyu tek bilenin Allah olduğu insanlara söylenmiştir. Ancak böyle olmakla birlikte konu hakkında çeşitli rivayetler anlatılmış; bazen sayıları dokuza bile çıkartılmıştır. Genel inanış onların yedi kişi ve bir köpekten ibaret olduğudur. İsimleri ise halk arasında yaygın olan gemi istifinde geçen adlarıdır.

Yedi Uyurların adlarının gemi şeklinde yazılmalarının sebebi 16. yüzyıldan itibaren Osmanlı donanmasının Ashâb-ı Kehf'e emanet edilmesi ve gemilere konan isimlerinin koruması altına alınmış olmasıdır. Yedi Uyurlar gemilerinde sadece isimler yer almaz; genellikle birinci yelkende "Ya malikü'I-mülk, el-Cabbar", ikinci yelkende Fetih Suresi, 1. Ayet, geminin bayraklarında da birinci bayrakta "Kelîme-i Tevhîd" ve diğerinde "Mâşâallah" ibareleri yazılmaktadır (Neumeier, 2013: 2-3).

Karakılınçlı Köyü Camii'nin doğu duvarı, kuzeydoğu köşesinde ve Yeniceköy Camii'nin mihrap kavsara köşeliği, batt tarafinda (Eryılmaz, 2018: 551, Fotoğraf 39) tuğra istifli hat içerisinde "Şefâ’atî li-ehli'I-kebairi min ümmet̂" yani "Benim şefaatim ümmetimden büyük günah işleyenleredir" hadisi yer almaktadır (Sünen-i Tirmizi, 2004: 2435; Fotoğraf 11). Yeniceköy Camii'nde ki tuğra hat mavi zemin üzerine altnn yaldızla ve daha yüksek bir ustalıkla yazılmıştır.

Her iki caminin mihrabında benzer iki kitabe daha bulunmaktadır. Kitabelerin yazı üslupları farklı olmakla beraber içerikleri aynıdır. Karakıııçlı Köyü Camii'nin kavsarasında perde motifinin aşağıya ilk boğumunda, celî sülüs istifli yazıda "Sübhâneke mâ abednâke Hakkun ibâdetike yâ Ma'bûd.", "Ey kulluk edilmeye en layık olan Allah `ım sana hakkıyla ibadet edemedik." anlamına gelen dua yazılmıştır (Fotoğ- 
raf 15). Aynı dua Yeniceköy Camii'nin mihrabında celî kûfi hatlı olarak karşımıza çıkmaktadır (Eryılmaz, 2018: 551, Fotoğraf 39).

Karakılınçlı Köyü Camii'nin mihrap nişinde stilize hayat ağacı şeklinde celî sülüs istifli hat yazıyla ve Yeniceköy Camii'nin mihrap nişi, bat yönündeki perde motifinde celî sülüs ile (Fotoğraf 41) Hicr Suresi'nin, 99. Ayeti yazılmıştır (Kur'an, 2011: 286).

Her iki yapının yazıları karşılaştırıldığında; Karakılınçlı Köyü Camii'nin ağırlıklı olarak celî sülüs istif yazılarla bezendiği, Yeniceköy Camii'nin ise daha çok celî kûfî istif hatlara sahip olduğu görülmektedir. Ayrıca Yeniceköy Camii'nin mihrap nişinde ustalıkla yazıımış celî sülüs müsennâ yazılar Karakılınçlı Köyü Camii'nde görülmemektedir (Fotoğraf 44-45). Her iki yapıda da armudi istifle yazılmış sanatçı imzasına rastlanmaktadır.

Karakılınçlı Köyü Camii'nin doğu duvarı ile mihrap nişinde gördügümüz celî dîvânî yazı, Divan-i Hümâyun'da resmi yazışmalarda kullanıldığı için dîvânî adını almıştır. Harekesiz yazılan dîvânînin 16. yüzyılda İstanbul'da, doğan üst düzey yazışmalarda kullanılan harekeli, süslü ve bir hayli zahmetli şekline celî dîvânî denilmiştir. Okunması ve yazılması maharet gerektirdiği için devlete ait sırların gizlenmesinde kullanıımıştır. Yazının özelliği satır sonlarının yukarıya doğru yükselmesidir (Derman, 2001: 17). Yazımı oldukça zor celî dîvânî hat sanatını Yunt Dağında bir köy camisinin duvarına uygulayabilen Hüseyin Avni'nin maharetli ve saray üslubunu bilen bir sanatçı olduğu anlaşılmaktadır.

Caminin doğu ve batı duvarlarında istifli hatla tuğra olarak yazılmış ayet ve hadis görülür. Tuğra imza olarak kabul edilen yazı Osmanlı Devletinde bir padişah adına yazılır onun sembolü olur ve o tahttan çekilene kadar onu kullanırdı. Padişahın amblemi ve devleti temsil eden bir semboldü. Tuğra padişahla birlikte babasının adı ve daima zaferler kazanmasını dileyen "el-muzaffer daima" şeklinde bir dua da ihtiva etmektedir. Zaman içinde sembol anlamını yitiren tuğra tarikat şeyhleri için yazıldığı gibi, ayet, hadis şeklinde yazıldığı da görülmeye başlanmıştır (Derman, 2001: 18). Karakılınçlı Köyü Camii'ndeki Besmele ve hadis hatlı tuğralar bu geleneğin devamı olarak karşımıza çıkmıştır.

Camide hat sanatının güzel bir örneği olarak damla ve armudi istifli yazılara rastlanmıştı. Özellikle armudi biçimin hat sanatında sevilerek kullanılmasının sebebi dengeli bir şekle sahip olması ve armut şeklinin istif yapmaya uygun olması şeklinde belirtilmiştir. Armudi istiflerde gövdede yazı olduğu gibi armudun sapına bağlanmış sağlı, sollu yapraklar içerisinde de yazılar istiflenmiştir. Bunların çoğu ayet olmakla birlikte farklı ibarelere de rastlanmıştır (Özkafa, 2016: 26). Karakılınçlı Köyü Camii'nde tahrip edilmiş armudi istifin okunabilen kısmı Hüseyin Avni ketebelidir. Yenice Köy Camii'nde de armudi istifle yazıımış sanatçı imzası bulunur ve burada sanatçının şecere bilgisi de bulunmaktadır. Buna göre Hüseyin Avni'nin baba adının Mustafa olduğu belirtilmiştir (Eryılmaz, 2018: 549).

Doğu ve bat duvarlarında karşılıklı olarak celî sülüs hatla yazılan büyük vav harleri yer alır. Tasavvuf kültürü ve düşüncesinde vav harfine çeşitli anlamlar yüklenmiştir. Bunlardan biri vav harfi, vahidiyeti ihtiva etmesi yönüyle Allah'ın birliğini ifade etmekte; yani tekliği simgelemektedir. Vahid olan; eşi benzeri olmayan, ortağı bulunmayan, tek ilah olan, kendisinden başka ilah bulunmayan, sıfatlarında ve işlerinde asla benzeri olmayan anlamlarını içerdiği belirtilmiştir (Özkafa, 2012: 2583).

Yunt Dağı bölgesinde, köy camilerinin plânları ve duvar örgü teknikleri incelendiğinde uzun yıllardır devam eden bir cami yapma geleneğinin bölgede bulunduğu anlaşılır. Anadolu'nun çoğu köylerinde olduğu gibi bölgede de eski camiler yıkılarak yerine modern kabul edilen betonarme yapılar yapılmıştır. Yeni camilerin kemerli son cemaat yeri ve yuvarlak kemer formları, harimin enine plânı, taş malzeme örgüsü 
gibi benzerlikler, erken tarihli yapıların tekrarlandı̆ı̆nı göstermektedir. Bunun en güzel örnekleri: Siyekli Köyü Camii, Karaahmetli Köyü Camii, Köseler Köyü Camii, Pınarköy Camii ve Karahüseyinli Köyü Camii'leridir (Gürbıyık, 2017: 54).

Osmanlı dönemi, Bursa Ulu Camii, Edirne Eski Camii, Edirne Muradiye Camii gibi anıtsal cami örneklerinde özellikle ibadet mekânları ve son cemaat yerlerindeki yazılar kimi zaman yapıların hat müzesi gibi değerlendirildiğine işaret etmektedir. Bununla birlikte Manisa çevresinde, içinde bitkisel bezemelerin olduğu camiler çoğunlukla olmakla birlikte bu kadar yoğun yazının görsel olarak kullanıldığı cami sayısının azlığı dikkat çekmektedir (Acun, 1999; Acun, 2013).

Ayrıca önemli bir husus; caminin hat yazılarında ciddi tahribatların tespit edilmesidir. Duvarlara yapılan badanalarda yazılar zarar görmüş, bir kısmının üzeri beyaz boya ile boyanmıştr. Bazı yazılarda temizlenmek istenmiş, bu temizleme işi hat yazılarındaki özgün boyaların akmasına neden olmuştur. Özellikle mihrabın kavsara alınlığında ve nişi içindeki yazılara kimyasal boyalarla müdahalelerde bulunularak yazıların hem üslubu, hem de kök boyadan gelen özgün rengi tamamen bozulmuştur. Bu bozulma altın yaldızlı stilize hayat ağacı motifli hat istifinin, kurşun rengi metal bir boyayla üzerinden geçilmesiyle hat safhaya ulaşmıştır. Yapının karakterini oluşturan yazı bezemeler üzerindeki doğal dokuya zarar veren kimyasal boyaların işin ehli kişiler tarafindan, uygun yöntem ve tekniklerle acilen temizlenmesi gerekmektedir.

Bu bağlamda yapının statiğinde bozulma meydana geldiğinden doğu cephede derin çatlaklar oluşmuştur. Çatlaklardan içeriye su sızdığından, içerde doğu duvarında nem oluşmuş ve duvar sıvasının altı boşalmıştr. Bu sebeple her an sıvaların patlama, dökülme ve yazıların kaybedilme ihtimali bulunmaktadır. Acilen yapının dengesinin sağlanarak, duvarlara müdahale edilmeli, çatlaklar kapatılmalı ve içerde sıva altındaki boşalmaların giderilmesi için enjeksiyonla dolgu yapılmalıdır. Bu uygulamanın yapının bütün duvarlarında gerçekleştirilmesi, enjeksiyon dolgu yöntemiyle sıva altındaki boşalmaların giderilmesi gerekmektedir.

Doğu ve batı duvarlarda yazıların üzerine yerleştirilen iç klima üniteleri de bir an önce kaldırılmalıdır.
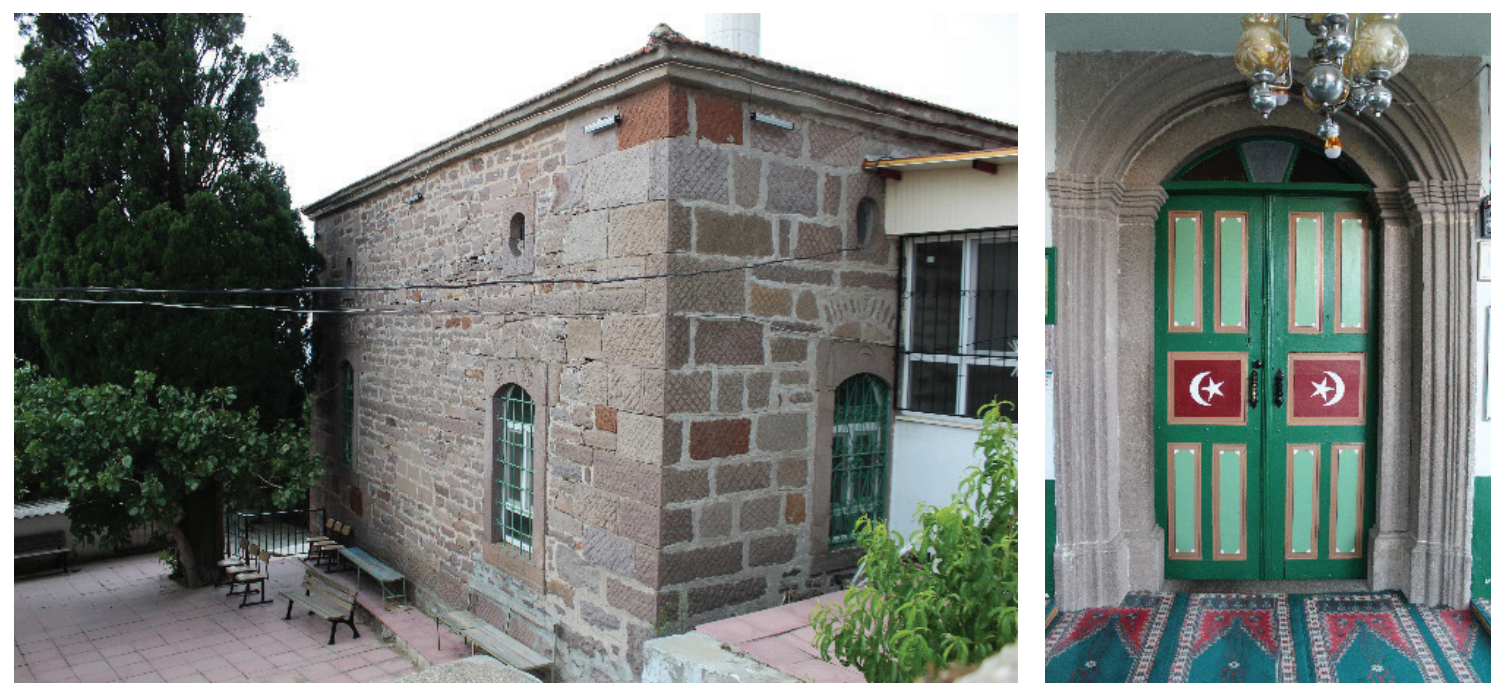
Ramazan Uykur
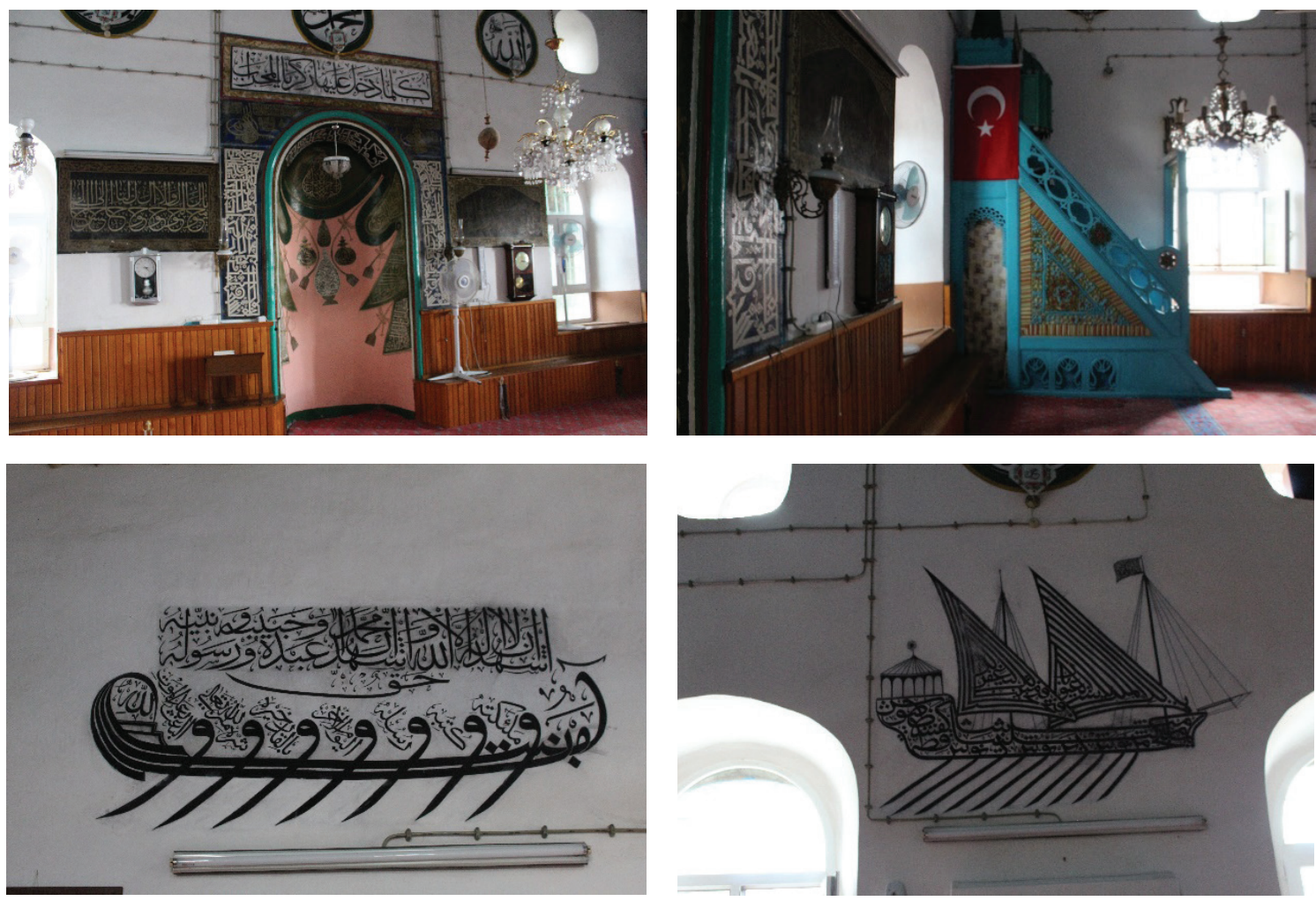

Fotoğraf 33-38. Yunt Dağı Yeniceköy Camii Fotoğraffları. En altta Yedi Uyurlar gemisi ve Amentü gemisi istifleri.
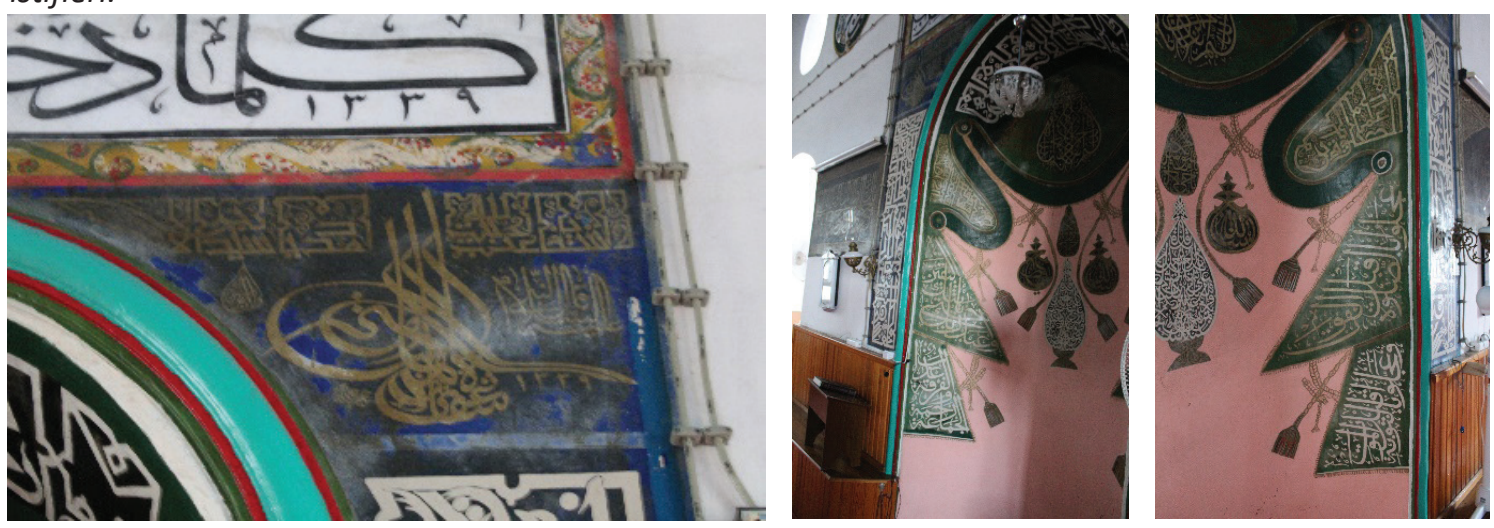

Fotoğraf 39-41. Yunt Dağı Yeniceköy Camii tuğra istifli hat ve mihrap nişinin perde motifinde bulunan istifli yazılar. 

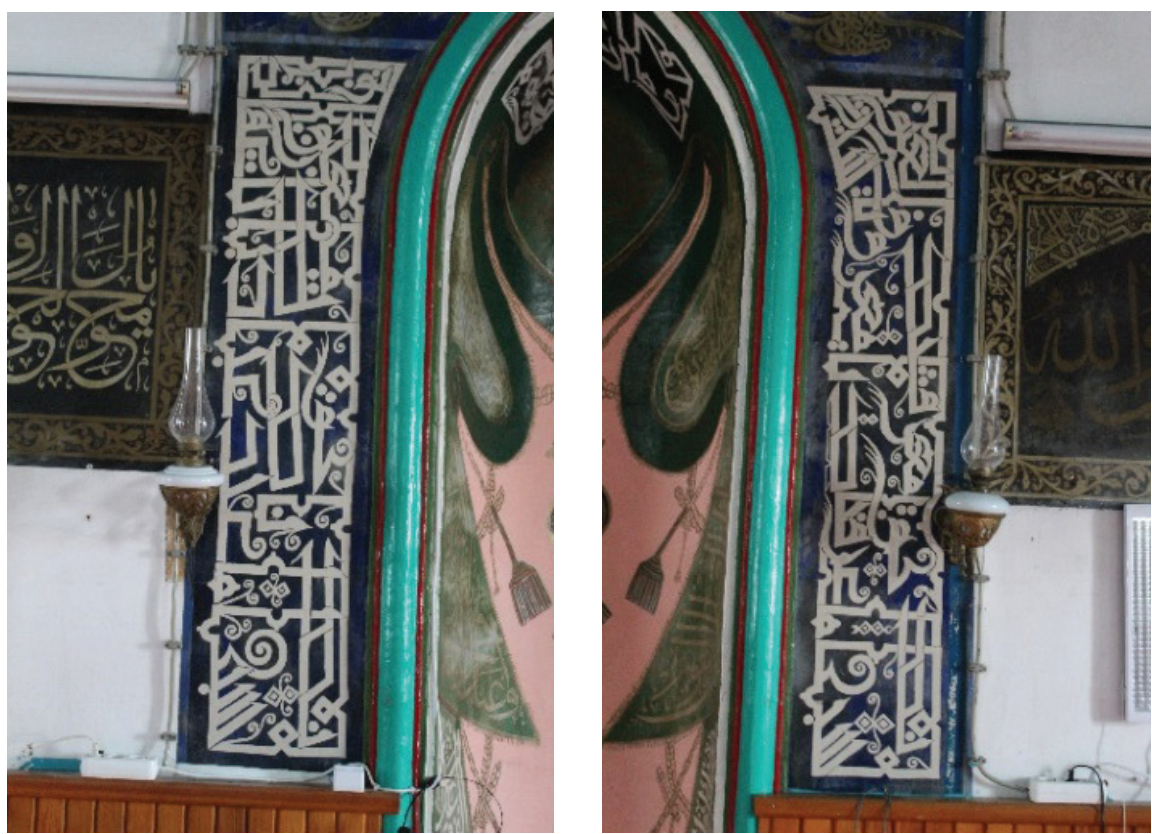

Fotoğraf 42, 43. Yunt Dağı Yeniceköy Camii, mihrap nişinin iki yanında yer alan celî kufi hatlı yazı şeritleri.
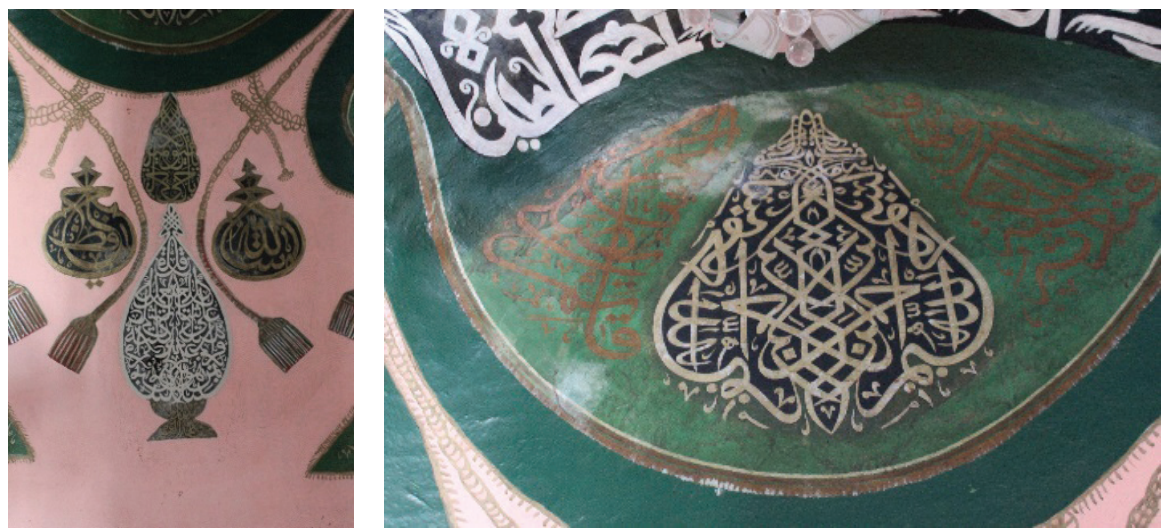

Fotoğraf 44-45. Yunt Dağı Yeniceköy Camii, mihrap nişinde celî sülüs müsennâ yazı istifleri.

\section{Sonuç}

Karakılınçlı Köyü Camii, kuzey cephesinde, son cemaat yeri kemeri üzerindeki taş kitabeye göre 1325H./1907-08M. tarihinde yapılmıştır. Kırmızı bazalt kesme taşından inşa edilen, yapı mihrap duvarına enlemesine gelişim gösteren bir harim ile kuzeyindeki son cemaat yerinden meydana gelmiştir. Son cemaat yerinin üzeri ise galeri katı şeklinde kadınlar mahfili olarak tasarlanmıştır.

Genel hatlarıyla bakıldığında yapının eklektik tarzda bir eser olduğu ve karma üsluplardan meydana geldiği görülür. Örneğin son cemaat yeri kemer gözleri ve kemerlerin oturduğu sütun başlıkları Neo Klasik üslupta, harime giriş sağlayan profilli taç kapı Gotik bir biçimde, gül pencere tasarımı ve mihrapta görülen perde motifi ise tamamen Batı sanatı etkisiyle yapılan, Geç Dönem Osmanlı eserlerinde karşımıza çıkan uygulamalardır.

Camide ustaca uygulanmış hat yazıları örneklerine rastlanır. Yapının doğu, güney ve batı duvarlarında beyaz zemin üzerine siyah ve altın yaldızla celî divânî, sülüs, kûfi, damla ve armudi istif hatla yazılmış kitabeler bulunur. Kitabelerin çoğunda Hüseyin Avni şeklinde sanatçı imzasına ve kitabelerin yazıldığı 


\section{Ramazan Uykur}

yıla yer verilmiştir. Kitabelerin bir kısmında çift şeritle, çerçeve içine kıvrım dal bitkisel bezeme dolgu yapılmıştır. Çerçevesiz yazılarda merkezdeki celî sülüs büyük vav harflerinin çevresinde istifli ayet yazıları ile tuğra şeklinde istiflenmiş tasarımlar uygulanmıştr. Mihrap nişinde bulunan püskülü perde motifinin her bir boğumunun içi celî sülüs, damla ve dîvânî istifli yazılarla bezenmiştir. Sanatçı hat sanatının inceliklerini sergilediği yazılar içinde bir de resimli yazı olarak isimlendirilen celî sülüs istif hatla yazılmış Yedi Uyurlar gemi resmini eklemiştir.

Yapı, Yunt Dağı'ndaki Yeniceköy Camii ile malzeme, duvar örgü tekniği, plân, taç kapılar, pencere biçimleri bakımından bire bir benzerlik yansıtır. Dolayısıyla bu iki camiyi aynı ustaların inşa ettiğini kabul edebiliriz. Üstelik her iki yapının hat yazılarını gezgin bir usta olan Hattat Hüseyin Avni yazmıştr.

Ancak yapıya karakterini veren hat yazılarında ne yazık ki tahribatlar tespit edilmiştir. Duvarlara yapılan badanalarda bir kısmının üzeri beyaza boyanmış, bazı yazılar temizlenmek istenirken boyalar akmış, yer yer de kimyasal boyalarla müdahalelerde bulunulmuştur. Bundan dolayı yapı bir an önce koruma altına alınarak, yazılar üzerindeki doğal dokuya zarar veren kimyasal boyaların işin ehli kişiler tarafindan, uygun yöntem ve tekniklerle temizlenmesi gerekmektedir.

Sonuç olarak Yunt Dağı bölgesinin çevreye nispetle henüz bakir sayılabilecek özelliklere sahip olduğu ve Türkmen geleneklerini hâlâ devam ettirdiği anlaşımaktadır. 
Yunt Dağı Karakılınçı Köyü Camii’nde Yazının Bezeme Unsuru Olarak Kullanımı ve Yapının Mimari Analizi

\section{Kaynaklar}

Acun, Hakkı (1999). Manisa'da Türk Devri Yapıları. Ankara T.T.K. Yayınları.

Akurgal, Ekrem (1993). Anadolu Uygarlıkları. 4. Baskı, İstanbul: Net Turistik Yayınlar A.Ş.

Derman, Uğur (2001). Osmanlı Hat Sanatı. İstanbul: Mas Matbaacılık A.Ş.

Emecen, Feridun M. (1989). XVI. Asırda Manisa Kazası. Ankara: TTK Basımevi.

Eroğlu, İlker ve Recep Bozyiğit (2012). "Yunt Dağı ve Çevresinin İklim Özellikleri”. Selçuk Üniversitesi Sosyal Bilimler Enstitüsü Dergisi, S. 27: 129-151.

Ersöz, İsmet (1991). “Ashâb-ı Kehf”, DiA, Cilt 3, İstanbul: 465-467.

Eryılmaz, Halil İbrahim (2018). "Yuntdağ Yenice Mahallesi Camii Yazıları". MCBÜ Sosyal Bilimler Dergisi, C. 16, S. $3: 545-580$.

Gökçen, İbrahim (1946). 16. ve 17. Asır Sicillerine Göre Saruhan'da Yörük ve Türkmenler. İstanbul: Manisa Halkevi Yayınları. XVI.

Gürbıyık, Cengiz (2017). "Yunt Dağı Ve Köyleri’nde Türk Dönemi Kültür Varlıkları Ve Korunma Sorunları”. Gelenek Ile Gelecek Arasında Kalmış Bir Bölge: Yuntdağı (Sorunlar Ve Öneriler). Ed. M. Tepekaya, F. Berber, C. Gürbıyık, B. Alacı, MCBÜ Yayınları, No: 0029. 51-62.

Harman, Ömer Faruk (2013). "Yûnus". DiA, Cilt 43, İstanbul. 597-599.

İloğlu, Mustafa (ty). Gizli illimler Hazinesi. Cilt 4. İstanbul: Seda Yayınları.

Kur'an-ı Kerim Meâli (2011). Ankara: Diyanet İşleri Başkanlığı Yayınları.

Muhyiddin en-Nevevî (ty). Riyâzü's-Sâlihîn. Cilt 3, Çev. M. E. Özafşar, B. Erul, Diyanet İşleri Başkanlığı Yayınları.

Neumeier, Emily ve İ. Cemil Schick (2013). "Hat San'atında Sefîne İstifleri ve Nuh'un Gemisi”, Nuh Kitabı, Ed. E. G. Naskali, Kitabevi, İstanbul. 221-233.

Öğüt, Salim (2008). "Saf". DiA, Cilt 35, İstanbul. 435-436.

Özkafa, Fatih (2012). "Kültürel ve Estetik Bakımdan “vav” Harfine Analitik Bir Yaklaşım”. Turkish Studies, Volume 7/4: 2577-2600.

Özkafa, Fatih (2016). "Hat Sanatında Armudî İstifler”. Klasik Sanatlar Yıllığı, Ed. F. Özkafa, İstanbul: Diyanet İşleri Başkanlığı Yayınları.

Sezgin, Yusuf (2017). “-Aigai- Yunt Dağı'nın Kısa Tarihi Ve Aigai Antik Kenti”. Gelenek Ile Gelecek Arasında Kalmış Bir Bölge: Yuntdağı (Sorunlar ve Öneriler). Ed. M. Tepekaya, F. Berber, C. Gürbıyık, B. Alacı, MCBÜ Yayınları, No: 0029. 21-51.

Sümer, Faruk (1989). Eshab-ü'l-Kehf (Yedi Uyurlar). İstanbul: Türk Dünyası Araşttrmaları Vakfi Yayınları. Sünen-i Tirmizi (2004). Haz. A. Parlıyan, Konya.

Türk Kültür Varlıları Envanteri 45. Manisa İlçeleri (2013). Ed. Hakkı Acun, Ankara: T.T.K. Yayınları.

Uluçay, M. Çağatay (1942). XVII inci Yüz Yılda Manisa'da Ziraat, Ticaret ve Esnaf Teşkilat I. İstanbul: Resimli Ay Matbaası.

(1955). 18 ve 19. Yüzyıllarda Saruhan'da Eşkıyalık ve Halk Hareketleri. İstanbul:

Berksoy Basımevi.

Yaşaroğlu, M. Kamil (2006). “Namaz”. DiA, Cilt 32, İstanbul. 350-357. 